\title{
PERUBAHAN NILAI BUDAYA URANG BANJAR (DALAM PERSPEKTIF TEORI TROOMPENAAR) ${ }^{1}$
}

\author{
Imadduddin Parhani \\ Fakultas Ushuluddin dan Humaniora IAIN Antasari Banjarmasin \\ Email: poenyaimad@gmail.com
}

\begin{abstract}
The study about Cultural Values of Urang Banjar (Banjarese) has not been done much. This study refers to the dimension of cultural values addressed by Troompenaar. According to Troompenaar, cultural values have seven dimensions; individualism - Communitarism, specific Relationship - Diffuse relationship, Universalism - Particularism, Neutral Relationship - Emotional Relationship, Achivemenent - ascription, Sequential time - Synchoronous time, and the Environment. The results of research conducted by Troompenaar in Indonesia indicate that Indonesia is in the category of Communitarism, Diffuse relationship, Particularism, Neutral Relationship, ascription, Synchoronous Time and Outter Direction. In this study, the data was collected through questionnaires which had been previously prepared using Troompenar's dimensions of cultural values. The total sample was 192 people. This study focused on urang Banjar, and their cultural values. The results of this study showed that the cultural values of urang Banjar are included in the category of universalism ( 78.13 percent), Komunitariasme (79.17 percent), Emotional (73), Specification ( 54.17 percent), Achievement 76.04 percent) synchronous (69,79 percent), and Outter direction (83.33 percent). There is also a difference or shift in cultural values in Banjarese society from Indonesian cultural values; from particularism into Universalism, from Neutral into Emotional, from Diffuse to be Specific, and of ascription into Achievement. The difference or shift in cultural values that occurred in Urang Banjar is caused by an ongoing process of social change in Banjarese society.
\end{abstract}

Keywords: Cultural Values, Urang Banjar, Dimensions of Cultural Values, Social Change.

Tulisan ini merupakan Pengembangan dari makalah yang pernah di presentasikan pada Konferensi International: Transformasi Sosial dan Intelektual Orang Banjar Kontemporer pada Tanggal 9 -10 Agustus 2016 di Hotel Aria Barito Banjarmasin. Kalimantan Selatan 


\section{Pendahuluan}

Keanekaramagaman budaya yang ada di Indonesia sebenarnya adalah sebuah kekayaan dan bukan sebuah kemiskinan. Bahwasanya Indonesia tidak memiliki identitas budaya yang tunggal bukan berarti bahwa Indonesia tidak memiliki jati diri. Akan tetapi dengan adanya keanekaragaman budaya yang ada membuktikan bahwa masyarakat Indoensia memiliki kualitas produksi budaya yang luar biasa apabila jika mengacu pada pengertian bahwa kebudayaan adalah hasil cipta manusia ${ }^{2}$.

Kebudayaan atau culture adalah keseluruhan pemikiran dan benda yang dibuat atau diciptakan oleh manusia dalam perkembangan sejarahnya. Ruth Benedict $(1934)^{3}$, melihat kebudayaan sebagai pola pikir dan berbuat yang terlihat dalam kehidupan sekelompok manusia dan yang membedakannya dengan kelompok lain. Sejumlah ahli umumnya sepakat bahwa kebudayaan adalah perilaku dan penyesuaian diri manusia berdasarkan hal-hal yang dipelajari/learning behavior.

Kebudayaan juga dapat dipahami sebagai suatu sistem ide/gagasan yang dimiliki suatu masyarakat lewat proses belajar dan dijadikan acuan tingkah laku dalam kehidupan sosial bagi masyarakat tersebut ${ }^{4}$. Sedangkan sistem budaya itu sendiri dapat dikatakan sebagai seperangkat pengetahuan yang meliputi pandangan hidup, keyakinan, nilai, norma, aturan, hukum yang diacu untuk menata, menilai, dan menginterpretasikan benda dan peristiwa dalam berbagai aspek kehidupannya. Nilai-nilai yang menjadi salah satu unsur sistem budaya, merupakan konsepsi abstrak yang dianggap baik dan amat bernilai dalam hidup, yang kemudian menjadi pedoman tertinggi bagi kelakuan dalam suatu masyarakat ${ }^{5}$.

Budaya Nasional adalah budaya yang dihasilkan oleh masyarakat bangsa tersebut sejak zaman dahulu hingga kini sebagai suatu karya yang dibanggakan yang memiliki kekhasan bangsa tersebut dan memberi identitas warga, serta menciptakan suatu jati diri bangsa yang kuat. Sifat khas yang dimaksudkan di dalam kebudayaan nasional hanya dapat dimanifestasikan pada unsur budaya bahasa, kesenian, pakaian, dan upacara ritual. Unsur kebudayaan lain bersifat universal sehingga tidak dapat memunculkan sifat khas, seperti teknologi, ekonomi, sistem kemasyarakatan, dan agama. Kebudayaan nasional sesungguhnya dapat berupa sumbangan dari kebudayaan lokal. Jadi, sumbangan beberapa kebudayaan lokal tergabung menjadi satu ciri khas yang kemudian menjadi kebudayaan nasional ${ }^{6}$.

Konsep kebudayaan Indonesia dibangun oleh para pendahulu kita. Konsep kebudayaan Indonesia disini mengacu kepada nilai-nilai yang dipahami, dianut, dan dipedomani bersama oleh bangsa Indonesia. Nilai-nilai inilah yang kemudian dianggap sebagai nilai luhur, sebagai acuan pembangunan Indonesia. Nilai-nilai itu antara lain adalah taqwa, iman, kebenaran, tertib, setia kawan, harmoni, rukun, disiplin, harga diri, tenggang rasa, ramah tamah, ikhtiar, kompetitif, kebersamaan, dan kreatif. Nilai-

\footnotetext{
2 Syarif Moeis, Pembentukan Kebudayaan Nasional Indonesia, (Bandung: Universitas Pendidikan Indonesia, 2009) h. 1

3 Ibid h. 3

${ }^{4}$ Konjaraningrat, Pengantar Imu Antropologi (Jakarta: Rineka Cipta, 1996) h 40

5 Syarif Moeis, Pembentukan...h. 3

${ }^{6}$ Ibid, h. 3
} 
nilai itu terdapat dalam sistem budaya etnik yang ada di Indonesia. Nilai-nilai tersebut dianggap sebagai puncak-puncak kebudayaan daerah, sebagaimana sifat/ciri khas kebudayaan suatu bangsa Indonesia?.

Nilai Budaya Nasional pada dasarnya masih memerlukan pengkajian yang mendalam dan memerlukan penelitian lanjutan seperti apakah nilai budaya tersebut ketika berada di dalam kontek lokal atau nilai budaya lokal. Setidaknya terdapat 2 (dua) penelitian awal tentang nilai budaya nasional yang pernah dilakukan di Indonesia, yaitu penelitian yang dilakukan oleh Hofstede (1983) dan penelitian yang dilakukan oleh Troompenaar (1997) $)^{8}$. Troompenaar membagi 5 orientasi hubungan yang mengarahkan pada cara-cara dimana oang menyesuaikan satu sama lainnya, serta 2 sikap yang mengarah pada waktu dan lingkungan. Merujuk pada hasil penelitian Troompenaar ${ }^{9}$, maka apabila dilihat dari dimensi-dimensinya maka Indonesia secara umum memiliki kategori Communitarism, Diffuse relationship, Particularism, Neutral Relationship, Ascription,syncronous, dan Outer Direction.

Secara lengkap, pengelompokan budaya antar bangsa sebagai yang telah diteliti oleh Troompenaar tersebut dapat dilihat pada tabel 1, pada tabel tersebut posisi nilai budaya nasional Indonesia berdasarkan pada dimensi-dimensi budaya nasional menurut Troompenaar dapat dibandingkan dengan nilai budaya negara lain.

\section{Tabel. 1}

\section{Pengelompokan Budaya Berdasarkan Penelitian Troompenaar}

\begin{tabular}{|c|l|c|c|c|c|c|c|c|c|c|c|}
\hline $\begin{array}{c}\mathbf{N} \\
\mathbf{0}\end{array}$ & Negara & $\begin{array}{c}\text { Individ } \\
\text { ualism } \\
\mathbf{e}\end{array}$ & $\begin{array}{c}\text { Comm } \\
\text { unitari } \\
\text { sm }\end{array}$ & $\begin{array}{c}\text { Specifi } \\
\mathbf{k}\end{array}$ & Diffuse & $\begin{array}{c}\text { Univer } \\
\text { salism }\end{array}$ & $\begin{array}{c}\text { Particu } \\
\text { larism }\end{array}$ & $\begin{array}{c}\text { Neutra } \\
\mathbf{1}\end{array}$ & $\begin{array}{c}\text { Emotio } \\
\text { nal }\end{array}$ & $\begin{array}{c}\text { Achiev } \\
\text { ement }\end{array}$ & $\begin{array}{c}\text { Ascri } \\
\text { ption }\end{array}$ \\
\hline 1 & Amerika & $\mathrm{X}$ & & $\mathrm{X}$ & & $\mathrm{X}$ & & & $\mathrm{X}$ & $\mathrm{X}$ & \\
\hline 2 & Inggris & $\mathrm{X}$ & & $\mathrm{X}$ & & $\mathrm{X}$ & & $\mathrm{X}$ & & $\mathrm{X}$ & \\
\hline 3 & Jepang & & $\mathrm{X}$ & & $\mathrm{X}$ & & $\mathrm{X}$ & $\mathrm{X}$ & & & $\mathrm{X}$ \\
\hline 4 & Tiongkok & & $\mathrm{X}$ & & $\mathrm{X}$ & & $\mathrm{X}$ & & $\mathrm{X}$ & & $\mathrm{X}$ \\
\hline 5 & Indoensia & & $\mathrm{X}$ & & $\mathrm{X}$ & & $\mathrm{X}$ & $\mathrm{X}$ & & & $\mathrm{X}$ \\
\hline 6 & Hongkok & & $\mathrm{X}$ & & $\mathrm{X}$ & & $\mathrm{X}$ & $\mathrm{X}$ & & & $\mathrm{X}$ \\
\hline 7 & Singapura & & $\mathrm{X}$ & & $\mathrm{X}$ & & $\mathrm{X}$ & $\mathrm{X}$ & & & $\mathrm{X}$ \\
\hline 8 & Argentina & $\mathrm{X}$ & & & $\mathrm{X}$ & & $\mathrm{X}$ & $\mathrm{X}$ & & $\mathrm{X}$ & \\
\hline 9 & Meksiko & $\mathrm{X}$ & & & $\mathrm{X}$ & & $\mathrm{X}$ & $\mathrm{X}$ & & $\mathrm{X}$ & \\
\hline 10 & Venezuela & & $\mathrm{X}$ & & $\mathrm{X}$ & & $\mathrm{X}$ & $\mathrm{X}$ & & & $\mathrm{X}$ \\
\hline 11 & Brasil & $\mathrm{X}$ & & $\mathrm{X}$ & & $\mathrm{X}$ & & & $\mathrm{X}$ & & $\mathrm{X}$ \\
\hline 12 & Perancis & & $\mathrm{X}$ & $\mathrm{X}$ & & $\mathrm{X}$ & & & $\mathrm{X}$ & & $\mathrm{X}$ \\
\hline 13 & Belgia & & $\mathrm{X}$ & $\mathrm{X}$ & & $\mathrm{X}$ & & & $\mathrm{X}$ & & $\mathrm{X}$ \\
\hline 14 & Spanyol & $\mathrm{X}$ & & & $\mathrm{X}$ & & $\mathrm{X}$ & $\mathrm{X}$ & & $\mathrm{X}$ & \\
\hline 15 & Italia & & $\mathrm{X}$ & & $\mathrm{X}$ & $\mathrm{X}$ & & & $\mathrm{X}$ & & $\mathrm{X}$ \\
\hline
\end{tabular}

Sumber: Troompenaar dan Turner ${ }^{10}$, Dayakisni dan Yuniardi ${ }^{11}$

Penelitian ini lebih menfokuskan kepada "Perubahan Nilai Budaya Urang Banjar", penelitian ini bukan berarti akan memunculkan keprimordialan daerah. Penelitian ini justru akan memberikan sumbangan informasi untuk melihat kekayaan Nilai Budaya

\footnotetext{
${ }^{7}$ Junus M Melalatoa, Sistem Budaya Indonesia (Jakarta: Kerjasama FISIP Universitas Indoensia dengan PT. Pamator, 1997) h 102.

8 Troompenaar, F dan Hampden Turner, F. Riding The Waves of Culture, (London: Nicholas Brealy Publishing, 1997) h.

9 Ibid h 20-100

${ }^{10}$ Ibid h 20-100

${ }^{11}$ Tri Dayakisni dan Salis Yuniardi, Psikologi Lintas Budaya, (Malang: UMM Press, 2012). h 63-64
} 
Nasional dengan menggunakan persfektif lokal, yaitu persfektif Urang Banjar.

Kategori dimensi nilai budaya yang meliputi individualism - Communitarism, Specifik Relationship - Diffuse relationship, Universalism - Particularism, Neutral Relationship Emotional Relationship, Achivemenent - Ascription, Sequential time Synchoronous time, dan The Environment sudah dihasilkan oleh penelitian Troompenaar ${ }^{12}$. Berbasis dimensi tersebut akan dilakukan interpretasi dan pembuatan prosisi hubungan dimensi nilai budaya nasional tersebut dengan nilai budaya Banjar. Mengingat bahwa sampai saat ini belum ada penelitian maupun tulisan yang mengkaitkan nilai budaya nasional dengan nilai budaya Banjar maka tulisan ini akan berusaha mengetahui: bagaimana skor dimensi nilai budaya Banjar yang didasarkan kerangka berpikir dimensi nilai budaya Troompenaar? Dan bagaimana hubungan antara skor dimensi nilai budaya Banjar baru yang dihasilkan dengan nilai budaya nasional dan nilai budaya Banjar pada masa lampau.

Tulisan ini merupakan penelitian awal yang mengarah pada usaha untuk menghadirkan gambaran tentang perubahan nilai budaya berbasis budaya Banjar yang dapat memberikan gambaran objektif tentang budaya Banjar itu sendiri. Penelitian ini memberikan kontribusi positif dalam kerangka penelitian di bidang Psikologi Lintas Budaya yang akan banyak meneliti tentang pengaruh aspek budaya terhadap praktikpraktik bermasyarakat, manajemen dan organisasi di suatu budaya, etnis, dan wilayah yang dalam hal ini adalah budaya Banjar

\section{Sekelumit Tentang Urang Banjar}

Menurut Idwar Saleh ${ }^{13}$, Banjar bukanlah suku karena tidak adanya kesatuan etnik. Banjar hanyalah grup atau kelompok besar, yang terdiri dari kelompok Banjar Kuala, kelompok Banjar Batang Banyu dan kelompok Banjar Banjar Pahuluan. Kelompok pertama tinggal di daerah Banjar Kuala sampai dengan daerah Martapura, kelompok kedua tinggal di sepanjang Sungai Tabalong dari muaranya di Sungai Barito sampai Kelua dan kelompok yang ketiga tinggal di kaki Pegunungan Meratus yang memanjang dari Tanjung sampai Pelaihari. Kelompok Banjar Kuala berasal dari kesatuan etnik Ngaju, kelompok Banjar Batang Banyu berasal dari kesatuan etnik Maanyan, dan kelompok Banjar Pahuluan berasal dari kesatuan etnik Bukit.

Senada dengan hal di atas, menurut Alfani Daud ${ }^{14}$, etnis Banjar adalah penduduk asli sebagian wilayah Provinsi Kalimantan Selatan. Mereka itu diduga berintikan penduduk asal Sumatera atau daerah sekitarnya, yang membangun tanah air baru di kawasan ini sekitar lebih dari seribu tahun yang lalu. Setelah berlalu masa yang lama sekali akhirnya,-setelah bercampur dengan penduduk yang lebih asli, yang biasanya dinamakan sebagai suku Dayak, dan dengan imigran-imigran yang berdatangan

\footnotetext{
${ }^{12}$ Troompenaar, F dan Hampden Turner, F. Riding The Waves of Culture, (London: Nicholas Brealy Publishing, 1997) h 20

${ }^{13}$ M. Idwar Saleh, Sekilas Mengenal Daerah Banjar dan Kebudayaan Sungainya Sampai Dengan Akbir Abad 19. (Banjarbaru: Museum Negeri Lambung Mangkurat Provinsi Kalimantan Selatan, 1986) h 10

${ }^{14}$ Alfani Daud, 1997. Islam dan Masyarakat Banjar: Deskripsi dan Analisis Kebudayaan Banjar, (Jakarta: RajaGrafindo Persada, 1997) h 38.
} 
belakangan maka terbentuklah setidaknya tiga subsuku, yaitu (Banjar) Pahuluan, (Banjar) Batang Banyu dan Banjar (Kuala). Bahasa yang mereka kembangkan dinamakan bahasa Banjar, yang pada asasnya ialah bahasa Melayu yang di dalamnya terdapat banyak sekali kosa kata asal Jawa dan asal Dayak.

Sesuai dengan geografi politik tradisional, Banjar adalah juga sebuah nama kerajaan Islam yang pada awalnya terletak di Banjarmasin. Dalam proses pembentukan Kerajaan Banjar Masih dengan Pelabuhan perdagangan yang disebut orang Ngaju sebagai Bandar Masih (Bandarnya orang Melayu) dijadikan sebagai Ibukota Kerajaan Banjar yang kemudian menjadi Banjarmasin ${ }^{15}$.

Kerajaan Banjar yang berkembang sampai abad ke 19 merupakan sebuah kerajaan Islam merdeka dengan nation atau bangsa Banjar sebagai bangsa dari Kerajaan Banjar. Pada akhir abad ke 19 ekspansi kolonial Belanda berhasil menguasai Kerajaan Banjar dan secara sepihak mengumumkan proklamasi penghapusan kerajaan Banjarmasin pada tanggal 11 Juni 1860. Wilayah kerajaan yang berhasil dikuasainya dijadikan Karesidenan Afdelling Selatan dan Timur Borneo (Residentiz Zuider en Osterafdeling Van Borneo). Sejak itulah bangsa Banjar turun derajatnya menjadi bangsa jajahan. Mereka tidak lain disebut sebagai suatu nation akan tetapi hanya sebagai Urang Banjar ${ }^{16}$.

Nama Banjar diperoleh karena mereka sebelum dihapuskan pada tahun 1860 adalah warga Kesultanan Banjarmasin atau disingkat Banjar, sesuai dengan nama ibukotanya pada saat berdirinya. Ketika ibukota dipindahkan ke daerah pedalaman, terakhir di Martapura. Nama tersebut akhirnya menjadi baku dan tidak berubah lagi ${ }^{17}$.

Islamisasi Banjarmasin yang berlangsung sejak abad ke 15 hingga abad ke 19 secara nyata telah menghasilkan potret baru di kawasan selatan, tengah dan tenggara Kalimantan (Borneo) yang menyangkut manusia Banjar secara keseluruhan. Secara dinamis Islam telah melakukan transformasi reliogisitas dan kultural masyarakat Banjarmasin, dari beragama Kaharingan dan Hindu-Budha kepada agama Islam. Transformasi reliogisitas dan kultural berlangsung secara menyeluruh dalam lingkup kawasan aliran sungai, dataran rendah dan pegunungan serta pantai sehingga transformasi lambat laut dialami komunitas etnis Melayu, Jawa, Dayak, Ngaju, Maanyan, Bukit, dan Lawangan yang secara amalgamasi mendapat sebutan baru sebagai 'Urang Banjar' atau 'Etnis Banjar'18.

Orang Islam identik disebut Melayu, orang-orang Dayak yang masuk Islam disebut masok Melayu. Orang Dagang adalah Urang Banjar, sedangkan Urang Banjar adalah orang Islam, orang Islam dan Urang Banjar adalah orang Melayu. Mulai dari pagi hari hingga tengah malam, ajaran agama Islam mengatur kehidupan umatnya dengan berbagai pelaksanaan ibadah, baik yang wajib maupun yang sunnat. Tata cara makan dan minum serta hukum-hukum makanan dan minuman yang dibolehkan

${ }^{15}$ Ideham dan M. Suriansyah, dkk (editor), Sejarah Banjar. (Banjarmasin: Pemerintah Provinsi Kalimantan Selatan, 2007) h 3.

${ }^{16}$ A. Gazali Usman, Urang Banjar Dalam Sejarah. (Banjarmasin: Lambung Mangkurat University Press, 1995/1996) h 3

${ }^{17}$ Akh. Fauzi Aseri, dkk, Alfani Daud: Riwayat dan Pemikirannya, (Banjarmasin: Antasari Press, 2009) h 117-118

${ }^{18}$ Yusliani Noor, Islamisasi Banjarmasin Abad ke-15 Sampai Ke-19. (Yogyakarta: Penerbit Ombak, 2016) h 402-403 
atau diharamkan telah diatur dalam hukum Islam. Hak dan kewajiban suami isteri, hubungan perkawinan juga diatur dalam hukum Islam. Pendeknya, hukum Islam telah menjadi sebuah pembeda ${ }^{19}$.

Menarik untuk disimak hasil penelitian Alfani Daud yang berjudul "Pembenihan serta Pemupukan Tata Nilai Sosial Budaya dalam Keluarga Indonesia untuk daerah Kalimanatan Selatan. Adapun temuan-temuan penelitian tersebut antara lain adalah berkenaan dengan makna hidup, nilai yang sudah membaku dalam masyarakat Banjar ialah "hidup untuk bekerja", dan "hidup untuk beramal ibadah". Secara umum terdapat perbedaan pola tata nilai orang tua dan pola tata nilai remaja. Sehingga dapat dikatakan nilai-nilai ini secara mantap telah berhasil diteruskan oleh para generasi orang tua kepada generasi remaja. Tetapi bila dilihat per komunitas, nampaknya ada pergeseran nilai, tetapi hanya berkenaan dengan nilai "hidup untuk beramal-ibadah". Dalam komunitas kota besar nilai ini yang dikalangan orang tua berada dalam kelas "agak kuat" bergeser menjadi "lemah" dikalangan remaja. Keadaan sebaliknya terjadi dalam komunitas kota kecil. Sedang dalam komunitas pedesaan nilai "hidup untuk beramal-ibadah" dikalangan orang tua turun menjadi "lemah" dikalangan remaja ${ }^{20}$.

Di bawah ini akan disampaikan beberapa unsur filsafat hidup etnis Banjar, baik yang bersifat positif maupun yang bersifat negatif ${ }^{21}$ :

1. Baiman. Yaitu setiap Urang Banjar meyakini adanya Tuhan/Allah. Setiap individu etnis Banjar selalu disuruh untuk mempelajari tentang rukun iman dan melaksanakan dengan rajin kelima rukun Islam. Bila belum mempelajari tentang keimanan dan rukun Islam ini dianggap keberagamaan orang Banjar belum sempurna.

2. Bauntung. Urang Banjar harus punya keterampilan hidup. Jadi Urang Banjar dari kecil sudah diajari keterampilan kejuruan, yaitu keterampilan yang dikaitkan dengan pekerjaan tertentu yang terdapat dilingkungannya. Hal ini bisa dilihat dari asal Urang Banjar tersebut misalnya orang Kelua punya keahlian menjahit, orang Amuntai punya keahlian membuat lemari, orang Alabio punya keahlian sebagai pedagang kain, Negara punya keahlian sebagai pedagang emas, membuat gerabah, membuat perahu/kapal, orang Mergasari punya keahlian sebagai pembuat anyaman, orang Martapura punya keahlian berdagang batu-batuan.

3. Urang Banjar selalu di ajari life skill atau keterampilan agar hidup bisa mandiri. Urang Banjar harus bekerja terus menerus, karena setiap kali selesai suatu tugas, tugas lain telah menanti.

4. Batuah. Arti berkah atau bermanfaat bagi kehidupan orang lain. Urang Banjar sebagai pemeluk agama Islam, tentu akan mengamalkan ajaran secara baik, yaitu agar hidupnya membawa kebaikan bagi orang lain. Karena sebaik-baik manusia adalah yang bermanfaat bagi orang lain. Jadi Urang Banjar dalam tatanan masa lalu maupun saat ini selalu diharapkan agar hidupnya berguna bagi dirinya, keluarga dan orang banyak. Agar bisa berguna bagi masyarakat, maka Urang Banjar harus

\footnotetext{
${ }^{19}$ Ibid h 402-403

${ }^{20}$ Sahriansyah, Sejarah Kesultanan dan Budaya Banjar (Banjarmasin : Antasari Press, 2015) h 13

${ }^{21}$ Ibid h 33-38
} 
memiliki iman yang kuat, ilmu yang bermanfaat dan beramal kebajikan.

5. Cangkal. Yaitu ulet dan rajin dalam bekerja. Urang Banjar harus bekerja keras untuk menggapai cita-cita, sehingga di masa lalu mereka suka merantau. Sifat cangka dalam bekerja adalah salah satu identitas orang Banjar. Dalam pandangan Urang Banjar bekerja harus maksimal, berdoa dan bertawakal kepada Allah SW'T, sehingga hidupnya akan bahagia di dunia dan akhirat.

6. Baik Tingkah laku. Yaitu Urang Banjar dalam pergaulan sehari-hari harus menunjukkan budi pekerti yang luhur agar dia disenangi orang lain. Dengan kata lain, Urang Banjar harus pandai beradaptasi dengan lingkungan di mana dia bertempat tinggal.

7. Kompetitif individual. Yaitu orang Banjar terkenal sebagai pekerja keras dalam menggapai cita-citanya tetapi bekerja sendiri-sendiri tidak secara kolektif, sehingga Urang Banjar tidak mampu membangun suatu poros kekuatan ekonomi atau politik di pentas nasional. Urang Banjar cenderung memiliki sifat individual dan ego yang tinggi sehingga susah diatur.

8. Materialis pragmatis. Gaya hidup Urang Banjar saat ini dikarenakan pengaruh globalisasi dengan trend hidup yang materialis-pragmatis, sehingga pola hidup Urang Banjar sangat konsumtif. Disisi lain, gaya hidup anak muda Banjar dalam memilih kerja, lebih mengutamakan kerja kantoran yang berdasi atau karyawan supermarket daripada pedagang kecil dengan modal sendiri dan mandiri.

9. Sikap qanaah dan pasrah. Urang Banjar selagi muda adalah pekerja keras untuk meraih cita-citanya, tapi kalau sudah berhasil dan sudah tua hidupnya santai untuk menikmati hidup dan beribadah kepada Allah untuk mengisi waktu.

10. Haram manyarah dan waja sampai kaputing. Yaitu pantang manyarah dan tegar pendirian. Kata hikmah di atas diungkapkan oleh Pangeran Antasari dalam rangka memperkuat motivasi pasukannya menghadapi pasukan penjajah Belanda. Urang Banjar mempunyai pendirian yang kuat untuk mempertahankan keyakinan atau yang diperjuangkannya, sehingga tidak mudah goyang atau terombang-ambing oleh situasi dan kondisi yang dihadapi.

\section{Nilai Budaya}

Nilai merupakan sesuatu yang berkaitan dengan aktivitas masyarakat baik secara kelompok maupun individu. Nilai yang muncul tersebut dapat bersifat positif apabila akan berakibat baik, namun akan bersifat negatif jika berakibat buruk pada objek yang diberikan nilai ${ }^{22}$. Nilai menunjuk pada sikap orang terhadap sesuatu yang baik. Nilai-nilai tersebut dapat saling berkaitan membentuk suatu sistem dan antara yang satu dengan yang lain saling koheren dan mempengaruhi segi kehidupan manusia. Dengan demikian, nilai-nilai berarti sesuatu yang metafisis, meskipun berkaitan dengan kenyataan kongkret. Nilai tidak dapat kita lihat dalam bentuk fisik, sebab nilai adalah harga sesuatu hal yang harus dicari dalam proses manusia menanggapi sikap manusia yang lain ${ }^{23}$.

\footnotetext{
${ }^{22}$ Munandar Sulaiman, Ilmu Budaya Dasar Suatu Pengantar, (Bandung: Refika Aditama, 1992) h 19

${ }^{23}$ Mardiatmaja, Tantangan Dunia Pendidikan. (Jogyakarta: Kanisius, 1986) h 105
} 
Nilai budaya merupakan nilai yang ada dan berkembang di dalam masyarakat. Menurut Koentjoroningrat ${ }^{24}$, nilai budaya itu adalah tingkat pertama kebudayaan ideal atau adat. Nilai budaya merupakan lapisan paling abstrak dan luas ruang lingkupnya. Jadi, nilai budaya adalah suatu yang dianggap sangat berpengaruh dan dijadikan pegangan bagi suatu masyarakat dalam menentukan seseorang berperikemanusiaan atau tidaknya.

Menurut Koentjaraningrat ${ }^{25}$, nilai budaya terdiri dari konsepsi - konsepsi yang hidup dalam alam fikiran sebahagian besar warga masyarakat mengenai hal - hal yang mereka anggap amat mulia. Sistem nilai yang ada dalam suatu masyarakat dijadikan orientasi dan rujukan dalam bertindak. Oleh karena itu, nilai budaya yang dimiliki seseorang mempengaruhinya dalam menentukan alternatif, cara - cara, alat - alat, dan tujuan - tujuan pembuatan yang tersedia.

Masih menurut Koentjoroningrat ${ }^{26}$, suatu sistem nilai-nilai budaya terdiri dari konsepsi-konsepsi yang hidup dalam alam pikiran sebagian besar masyarakat mengenai hal-hal yang harus mereka anggap sangat bernilai dalam hidup. Oleh karena itu, suatu sistem nilai budaya biasanya berfungsi sebagai pedoman tertinggi bagi kelakukan manusia. Sistem tata kelakuan manusia yang tingkatannya lebih kongkrit seperti aturan-aturan khusus, dan nilai budaya tersebut.

Koentjoroningrat ${ }^{27}$ mengungkapkan bahwa nilai budaya dikelompokkan ke dalam lima pola hubungan, yakni: 1) nilai budaya dalam hubungan manusia dengan Tuhan, 2) nilai budaya dalam hubungan manusia dengan alam, 3) nilai budaya dalam hubungan manusia dan masyarakat, 4) nilai budaya dalam hubungan mansuai dengan orang lain atau sesama, 5) nilai budaya dalam hubungan manusia dengan dirinya sendiri.

Menurut C. Kluckhom dan Stradbeck, F.L ${ }^{28}$, sistem nilai budaya dalam semua kebudayaan di dunia, secara universal menyangkut lima masalah pokok kehidupan manusia, yaitu:

1. Hakekat hidup manusia: hakekat hidup untuk setiap kebudayaan berbeda secara ekstern. Ada yang berusaha untuk memadamkan hidup, ada pula dengan polapola kelakuan tertentu.

2. Hakekat karya manusia: setiap kebudayaan hakekatnya berbeda-beda, untuk hidup, kedudukan/kehormatan, gerak hidup untuk menambah karya.

3. Hakekat waktu manusia: hakekat waktu untuk setiap kebudayaan berbeda-beda, orientasi masa lampau atau untuk masa kini.

4. Hakekat alam manusia: ada kebudayaan yang menganggap manusia harus mengekploitasi alam, ada juga yang harus harmonis dengan alam atau manusia menyerah kepada alam.

5. Hakekat hubungan manusia: mementingkan hubungan antar manusia baik vertikal maupun horizontal (orientasi pada tokoh-tokoh). Ada pula berpandangan individualis.

\footnotetext{
${ }^{24}$ Koentjorongrat, Kebudayaan Jawa. (Jakarta: Balai Pustaka, 1984) h 8-25

${ }^{25}$ Koentjaraningrat, Pengantar Ilmu Antropologi, (Jakarta: Balai Pustaka, 1987) h 85

${ }^{26}$ Koentjorongrat, Kebudayaan...h 3

${ }^{27}$ Koentjorongrat, Kebudayaan...h 4

${ }^{28}$ Kluckhon, F.R dan Stradtbeck, F.L, Variations in value orientation, (Evanston: Row Peterson, 1961) h 5
} 
Apabila kita mendiskusikan nilai-nilai budaya maka orientasi kita tidak harus melihat ke masa lalu dan cenderung mengabaikan manfaatnya pada masa yang akan datang. Kita perlu mendiskusikan nilai-nilai budaya apa saja yang perlu digali, dikembangkan atau direkayasa sebagai pembentuk sebuah karakter (watak, akhlak, dan kepribadian) budaya agar dapat menopang kemajuan sebuah kesejahteraan. Sebaliknya juga pemahaman akan nilai-nilai budaya ini memberikan gambaran kepada nilai-nilai budaya atau kebiasaan yang layak untuk dihilangkan atau dirubah karena jika terus dikembangkan akan menghambat sebuah kemajuan.

\section{Nilai Budaya Troompenaar}

Salah satu pendekatan untuk studi budaya adalah melalui identifikasi dan pengukuran dimensi budaya, dan beberapa tipologi orientasi dimensi budaya pada saat ini telah dikembangkan. Pada bagian ini, akan dijelaskan mengenai model dimensi budaya yang mempunyai pengaruh terhadap nilai budaya.

Morden $^{29}$ (1999:19-44) mengidentifikasi bahwa ada tiga kategorisasi dalam budaya yaitu singles dimensions models, multipledimension model dan bistorical social models. Sebagaimana yang tergambar dalam tabel berikut ini:

\section{Tabel 2: Model Nilai Budaya}

\begin{tabular}{|l|l|l|}
\hline \multicolumn{1}{|c|}{ Model } & \multicolumn{1}{|c|}{ Sumber } & \multicolumn{1}{c|}{ Dimensi Budaya } \\
\hline Single Dimension & Hall (1990) & Hight Contex-Low Context \\
\cline { 2 - 3 } & Lewis (1992) & Monochronic-Polychronic \\
\cline { 2 - 3 } & Fukuyama (1995) & High Trust-Low Trust \\
\hline Multiple Dimension & Hofstede (1980,1983) & Powe Distance \\
Individualism-Collectivism \\
\end{tabular}

${ }^{29}$ T. Morden. 1999. Models Of National Culture-A Management Review. Cross Cultural Management(An International Journal 6 (1). Hal 19-44 


\begin{tabular}{|l|l|l|}
\hline Historical-Social & $\begin{array}{l}\text { Bloom, Calori \& de Woot } \\
(1994\end{array}$ & Euromanagement Model \\
\cline { 2 - 3 } & Chen (1995 & South East Asian Management Model \\
\hline
\end{tabular}

Di antara sekian banyak studi dan teori tentang nilai budaya tersebut salah satunya yang diakui besar pengaruhnya adalah teori nilai yang disusun oleh Trompenaar dari Belanda Dimensi budaya dari Troompenaar paling populer dalam studi pengaruh nilai budaya dalam bidang manajemen dan diakui secara luas sebagai cultural framework. yang penting dalam menjelaskan perbedaan budaya antar bangsa. Studi yang dilakukan oleh Troompenaar adalah studi yang cukup lengkap menjelaskan dimensi nilai budaya mulai dari segi konseptual hingga pengukuran dalam bentuk indikator-indikator ${ }^{30}$.

Trompenaar melakukan penelitian selama lebih dari 10 tahun dengan menyebar kuesioner pada lebih dari 15.000 manajer dari 28 negara. Penyusunan teorinya didasarkan kepada orientasi nilai dan orientasi relasi/hubungan yang telah dikenalkan oleh sosiolog Talcott Parsons ${ }^{31}$.

Secara lebih rinci tentang uraian dimensi-dimensi nilai dari Trompenaar adalah sebagai berikut ${ }^{32}{ }^{33}{ }^{34}$ :

1. Universalism versus Particularsm (Apa yang lebih penting, aturan atau hubungan?)

2. Universalisme adalah keyakinan bahwa ide-ide dan praktek-praktek dapat diterapkan dimana saja tanpa dimodifikasi. Sedangkan partikularisme adalah keyakinan bahwa lingkungan sekitar mendiktekan bagaimana ide-ide dan praktek-praktek seharusnya diterapkan.

3. Dalam budaya dengan dimensi universalisme yang tinggi di tandai adanya fokus pada aturan-aturan formal daripada hubungan. Sebaliknya dalam budaya dengan dimensi partikularisme yang tinggi, fokus lebih pada hubungan dan kepercayaan daripada aturan-aturan formal, kontrak legal hampir selalu dimodifikasi menyesuaikan dengan keadaan bahkan hampir selalu merubah cara-cara dimana kesepakatan itu dilaksanakan

4. Individualism versus communitarism (Apakah kita berfungsi dalam kelompok atau sebagai individu?)

5. Yang dimaksud dengan individualisme adalah orang-orang yang menggangap diri mereka sebagai individu yang otonom, sementara communitarism mengacu pada orang-orang yang menganggap diri mereka sebagai bagian dari kelompok.

6. Neutral versus Emotional (Apakah kita menunjukkan emosi?)

7. Budaya neutral adalah suatu budaya dimana emosi selalu dalam pengontrolan. Individu di budaya ini mencoba untuk tidak memperlihatkan perasaan mereka; mereka bertindak dengan mengendalikan emosi dan mempertahnkan ketenangan.

\footnotetext{
${ }^{30}$ Tri Dayakisni dan Salis Yuniardi, Psikologi Lintas Budaya, (Malang: UMM Press, 2012). h 59

${ }^{31}$ Ibid h 59

${ }^{32}$ Ibid h 59

${ }^{33}$ Troompenaar, F dan Hampden Turner, F. Riding The Waves of Culture, (London: Nicholas Brealy Publishing, 1997) h $20-100$

${ }^{34}$ Tim Indohun, Pedoman Aplikasi Soft Skill One Health, (Jakarta: Fakultas Kesehatan Masyarakat Universitas Indonesia, Tahun Tidak Ada) h 83
} 
Sementara budaya emosional adalah budaya dimana emosi-emosi diekpresikan secara terbuka dan spontan/alami. Orang-orang di budaya ini cenderung untuk tertawa lebar, berbicara dengan keras ketika keheranan dan selalu memberi salam dengan antusias.

8. Specific versus Diffuse (Seberapa terpisah kehidupan pribadi dan pekerjaan kita)

9. Budaya khusus (spesific culture) adalah budaya dimana individu-individu memiliki ruang publik yang luas yang siap mereka bagi dengan orang-orang lain dan ruang pribadi yang sempit yang mereka jaga secara ketat dan dibagi hanya dengan temanteman akrab. Sementara budaya kabur (diffuse culture) adalah budaya dimana baik ruang publik dan ruang pribadi adalah sama ukurannya dan individu-individu menjaga ruang publik mereka secara hati-hati, karena masuk ke dalam ruang publik akan membuka masuk kedalam ruang pribadi juga.

10. Achivement versus Ascription (Apakah status diperoleh dengan membuktikan diri atau merupakan pemberian?)

11. Dimensi ini mengacu pada pertanyaan apakah status seseorang diberikan berdasarkan agama, asal usul, atau usia, atau apakah status merupakan pengakuan terhadap kinerja individu yang telah terbukti. Budaya prestasi (Achivement culture) adalah budaya dimana orang-orang memberi status berdasarkan pada sejauhmana kualitas (baiknya) mereka menampilkan fungsi mereka. Sedangkan Ascription culture adalah budaya dimana status diatribusikan berdasarkan pada siapa atau apakah orang itu. Budaya prestasi memberikan status tinggi kepada mereka yang prestasinya tinggi. Sedangkan ascription culture memberikan status berdasarkan pada usia, gender, atau koneksi sosialnya.

12. Sequential time versus synchronous time (Apakah kita melakukan hal-hal satu per satu atau beberapa hal sekaligus?)

13. Dalam budaya dengan pendekatan sequential adalah umum bahwa orangorang cenderung untuk melakukan hanya satu aktivitas dalam satu waktu, mempertahankan janji dengan ketat, dan menunjukkan pilihan yang kuat untuk mengikuti rencana-rencana sebagaimana yang telah ditetapkan dan tidak menyimpang dari rencana itu. Sementara dalam budaya dengan pendekatan synchronous, individu cenderung untuk melakukan lebih dari satu aktifitas pada satu waktu, janji adalah kira-kira dan kemungkinan dirubah pada saat waktu tertentu, dan penjadwalan pada umumnya di bawah kepentingan hubungan dan dibolehkan untuk melakukan interupsi atas skedul itu.

14. The Environment (apakah kita mengontrol lingkungan atau dikontrol oleh lingkungan?)

15. Perhatian khusunya adalah diarahkan kepada bagaimana mereka memiliki keyakinan dalam mengendalikan atau mengontrol hasil (inner directed) atau membiarkan sesuatu di luar diri mereka mengendalikan dirinya (outer directed). Orang-orang dengan budaya pengendalian internal cenderung untuk mengidentifikasi diri dengan mekanisme, yaitu, organisasi dipahami sebagai sebuah mesin yang mematuhi kehendak operatornya. Orang-orang di budaya kontrol eksternal cenderung melihat organisasi itu sendiri sebagai produk alam, yang berkembang karena adanya nutrisi dari lingkungannya dan keseimbangan 
ekologi yang menguntungkan.

\section{Profil Responden}

Total sampel dalam penelitian yang diperoleh adalah 192. Berikut ini adalah ringkasan profil responden sebagaimana dalam tabel-tabel berikut:

Tabel 3: Jenis Pekerjaan

\begin{tabular}{|c|c|c|c|}
\hline No & Jenis Pekerjaan & Jumlah & Persentase \\
\hline 1 & Pegawai Negeri Sipil & 53 & 27,60 \\
\hline 2 & Pegawai Swasta & 46 & 23,96 \\
\hline 3 & Pedagang & 10 & 5,21 \\
\hline 4 & Pelajar/Mahasiswa & 46 & 23,96 \\
\hline 5 & Petani/Peternak & 9 & 4,69 \\
\hline 6 & Ibu Rumah Tangga & 16 & 8,33 \\
\hline 7 & Tidak Bekerja & 12 & 6,25 \\
\hline & Total & $\mathbf{1 9 2}$ & $\mathbf{1 0 0}$ \\
\hline
\end{tabular}

Dari tabel di atas terlihat bahwa dari Pegawai Negeri Sipil (27,60 persen) kemudian disusul oleh Pegawai Swasta dan Pelajar/Mahasiswa (masing-masing 23,96 Persen).

Tabel 4: Jenis Kelamin

\begin{tabular}{|c|c|c|c|}
\hline No & Jenis Kelamin & Jumlah & Persentase \\
\hline 1 & Laki-laki & 76 & 39,58 \\
\hline 2 & Perempuan & 116 & 60,42 \\
\hline & Total & $\mathbf{1 9 2}$ & $\mathbf{1 0 0}$ \\
\hline
\end{tabular}

Jenis kelamin responden dapat dilihat pada tabel di atas dimana terdapat 76 lakilaki (39,58 Persen) serta perempuan berjumlah 116 orang (60,42 Persen). Sedangkan tingkat pendidikan responden terlihat dalam tabel dibawah ini yaitu terdapat 2 responden bergelar doktor, 17 responden orang bergelar magister, 59 berpendidikan strata 1, dan 87 berlatar pendidikan SMU.

Tabel 5: Pendidikan

\begin{tabular}{|c|c|c|c|}
\hline No & Pendidikan & Jumlah & Persentase \\
\hline 1 & Doktoral/S3 & 2 & 1,04 \\
\hline 2 & Strata 2/S2 & 17 & 8,85 \\
\hline 3 & Sarjana/S1 & 59 & 30,73 \\
\hline 4 & SMU/SMK & 87 & 4,31 \\
\hline 5 & SMP/SLTP & 12 & 6,25 \\
\hline 6 & SD/ & 15 & 7,81 \\
\hline 7 & Tidak Tamat SD & 0 & 0,0 \\
\hline & Total & $\mathbf{1 9 2}$ & $\mathbf{1 0 0}$ \\
\hline
\end{tabular}


Sedangkan berdasarkan posisi komunitas, maka komunitas terbesar adalah berasal dari Komunitas Kota Besar yaitu sebanyak 106 orang (55,21 Persen) disusul Komunitas Kota Kecil 46 orang (23,96 Persen) dan Komunitas Pedesaan adalah 40 orang (20,83 Persen)

\section{Tabel 6: Komunitas}

\begin{tabular}{|c|c|c|c|}
\hline No & Komunitas & Jumlah & Persentase \\
\hline 1 & Kota Besar & 106 & 55,21 \\
\hline 2 & Kota Kecil & 46 & 23,96 \\
\hline 3 & Pedesaan & 40 & 20,83 \\
\hline & Total & $\mathbf{1 9 2}$ & $\mathbf{1 0 0}$ \\
\hline
\end{tabular}

Apabila ditinjau dari kelompok usia maka dominan berasala dari kelompok Dewasa yaitu sebanyak 114 orang (59,38 persen), dan Remaja sebanyak 78 orang (40,63 persen). Sebaran data dapat dilihat pada tabel di bawah ini

Tabel 7: Kelompok Usia

\begin{tabular}{|c|c|c|c|}
\hline No & Kelompok Usia & Jumlah & Persentase \\
\hline 1 & Remaja & 78 & 40,63 \\
\hline 2 & Dewasa & 114 & 59,38 \\
\hline & Total & $\mathbf{1 9 2}$ & $\mathbf{1 0 0}$ \\
\hline
\end{tabular}

\section{Hasil Perhitungan Skor Dimensi Nilai Budaya Banjar}

1. Universalisme versus Partikularisme

\begin{tabular}{|c|c|c|}
\hline Dimensi & Jumlah & Persentase \\
\hline Universalisme & 150 & 78,13 \\
\hline Partikularisme & 42 & 21,88 \\
\hline Total & 192 & 100 \\
\hline
\end{tabular}

Urang Banjar masuk dalam kategori Universalisme dengan prosentase 78,13 persen

2. Individualisme versus Komunitarisme

\begin{tabular}{|c|c|c|}
\hline Dimensi & Jumlah & Persentase \\
\hline Individualisme & 40 & 20,83 \\
\hline Komunitarisme & 152 & 79,17 \\
\hline Total & 192 & 100 \\
\hline
\end{tabular}


Urang Banjar masuk dalam kategori Komunitarisme dengan prosentase 79,17 persen

3. Netralversus Emosional

\begin{tabular}{|c|c|c|}
\hline Dimensi & Jumlah & Persentase \\
\hline Neutral & 51 & 26,56 \\
\hline Emotional & 141 & 73,44 \\
\hline Total & 192 & 100 \\
\hline
\end{tabular}

Urang Banjar masuk dalam kategori Emotional dengan prosentase 73,44 persen

4. Spesifik versus Difusi

\begin{tabular}{|c|c|c|}
\hline Dimensi & Jumlah & Persentase \\
\hline Spesific & 104 & 54,17 \\
\hline Difusi & 88 & 45,83 \\
\hline Total & 192 & 100 \\
\hline
\end{tabular}

Urang Banjar masuk dalam kategori Spesific dengan prosentase 54,17 persen

5. Acbivement versus Askripsi

\begin{tabular}{|c|c|c|}
\hline Dimensi & Jumlah & Persentase \\
\hline Achivement & 146 & 76,04 \\
\hline Askripsi & 46 & 23,96 \\
\hline Total & 192 & 100 \\
\hline
\end{tabular}

Urang Banjar masuk dalam kategori Achievement dengan prosentase 76,04 persen

6. Sikap terhadap waktu

\begin{tabular}{|c|c|c|}
\hline Dimensi & Jumlah & Persentase \\
\hline Sequential & 58 & 30,21 \\
\hline Sychronous & 134 & 69,79 \\
\hline Total & 192 & 100 \\
\hline
\end{tabular}

Urang Banjar masuk dalam kategori Synchronous dengan prosentase 69,79 persen 7. Sikap terhadap Lingkungan

\begin{tabular}{|c|c|c|}
\hline Dimensi & Jumlah & Persentase \\
\hline Inner Direction & 32 & 16,67 \\
\hline Outter Direction & 160 & 83,33 \\
\hline
\end{tabular}




\begin{tabular}{|c|c|c|}
\hline Total & 192 & 100 \\
\hline
\end{tabular}

Urang Banjar masuk dalam kategori Outter Direction dengan prosentase 83,33 persen

\section{Analisis terhadap Hasil Dimensi-Dimensi Nilai Budaya}

\section{Analisis Terhadap Hasil Universalisme versus Partikularisme}

Troompenaar ${ }^{35}$, menggolongkan dua kelompok masyarakat dalam dimensi budaya, yaitu Partikularisme dan Universalisme. Partikularisme lebih mengedepankan aspek-aspek personal yang dilandasi oleh adanya hubungan emosional dibandingkan dengan peraturan yang berlaku saat itu, sedangkan dimensi universalisme lebih menfokuskan kepada tanggung jawab tiap individu kepada peraturan-peraturan yang ada daripada memikirkan nasib orang walaupun masih ada hubungan saudara. Setiap manusia dilahirkan dengan kodrat yang sama, memiliki hak dan kewajiban yang sama, tinggal bagiaman individu menjalani hidup ini, apakah menuntut hak dan menjalankan kewajiban yang ada. Hasil riset yang dilakukan di Indonesia menunjukkan bahwa masyarakat Asia termasuk di dalamnya Indonesia lebih dominan partikularisme daripada universalisme.

Namun di dalam penelitian yang dilakukan ini, menunjukkan hasil yang berbeda. Ternyata di dalam masyarakat Banjar terjadi perbedaan atau mungkin pergeseran nilai budaya yang di anut oleh sebagian masyarakat, yaitu sebanyak 78,13 persen berada di posisi Universalisme. Prosentase ini menunjukkan bukan berarti bahwa semua masyarakat Banjar dominan Universalisme dan minoritas partikularisme.

Apabila kita hubungkan dengan masyarakat Banjar dalam kesehariannya maka terlihat sejumlah tata kelakuan yang mengarah kepada Universalisme semisal seorang pemimpin di masyarakat harus membimbing karyawan atau warganya untuk menciptakan kehidupan yang dicari, berusaha melayani keperluan warganya tanpa pamrih. Dalam hal pekerjaan, seorang pemimpin harus mendahulukan kepentingan warga/masyarakat daripada kepentingan diri pribadi atau keluarganya. Pemimpin tidak boleh memihak apabila terjadi persoalan di antara karyawan atau warganya. Ia harus mencari penyelesaian yang sebaik-baiknya dengan tetap berpegang kepada peraturan yang berlaku ${ }^{36}$.

Suatu sistem nilai yang dipertahankan dalam sebuah masyarakat sering menyangkut apa yang menjadi fungsi dasarnya bagi struktur masyarakat tersebut. dalam kasus masyarakat Banjar yang secara historis selalu diidentikkan dengan Islam misalnya. Islam tentunya, disini tampil sebagai pencerminan suatu sistem nilai yang dipegang oleh masyarakat Banjar. Artinya, dalam banyak hal perilaku-perilaku orang Banjar dapat dicarikan referensi perilaku, fungsi keberislaman oleh masyarakat Banjar akhirnya menjadi simbol identitas yang membedakan dengan kelompok lainnya ${ }^{37}$.

35 Troompenaar, F dan Hampden Turner, F. Riding The Waves of Culture, (London: Nicholas Brealy Publishing, 1997) h 30

${ }^{36}$ Ideham dan M. Suriansyah, dkk (editor), Sejarah Banjar. (Banjarmasin: Pemerintah Provinsi Kalimantan Selatan, 2007) h 218

${ }^{37}$ Irfan Noor, Ulama dan Masyarakat Banjar. (Dalam Jurnal Kandil Melintas Tradisi Edisi 1, Tabun I. Mei 2003) h 18-25 
Dalam hal nilai-nilai beragama, masyarakat suku Banjar pada umumnya taat menjalankan kewajiban agama. Mereka biasanya menyelenggarakan salat Jumat atau salat lainnya secara berjamaah di masjid, suarau atau di rumah seseorang. Begitu pula penyelenggaraan upacara keagamaan seperti peringatan Isra Mikraj, peringatan Maulid dan penyelenggaraan upacara kematian. Setiap individu secara sendiri atau bersama dituntut untuk melaksanakan kewajibannya sesuai dengan ajaran agama yang dianut ${ }^{38}$.

Tata kelakuan yang berlaku di ranah keagamaan ini dilandasi oleh tuntutan agama. Dalam agama Islam kepada penyelenggara atau pimpinan upacara, juga pesertanya dituntut suatu persyaratan untuk memenuhi sah tidaknya ibadah yang dilakukan. Setiap orang tanpa memandang asal-usul, tingkatan sosial dan jabatannya harus memenuhi syarat-syarat sesuai dengan ketentuan agama ${ }^{39}$.

Dalam ranah ekonomi, maka masyarakat Banjar yang beragama Islam dengan pekerjaan sebagai penjual dituntut bersikap jujur dalam memberi untung (laba). Sesama penjual harus dapat merahasiakan kelemahan masing-masing. Landasan dasar tata kelakuan pergaulan antara penjual dengan penjual adalah agama, adat istiadat, dan keyakinan. Penjual siap menolong jika pembeli benar-benar memerlukan untuk mendesak dengan cara meminjam terlebih dahulu (utang) dan dibayar belakangan menurut perjanjian tanpa menaikkan harganya ${ }^{40}$.

Dalam hal terjadi kesepakatan jual beli, saat penyerahan uang, pembeli melakukannya dengan tangan kanan. Begitu juga penjual menerimanya dengan tangan kanan dibarengi ucapan: "ku jual barang-barang seharga" dengan menyebut jumlahnya. Pembeli pun membalasnya dengan perkataan "ku tukar barang ini seharga" sesuai hasil tawar menawar. Bagi penjual dan pembeli akad jual beli itu penting, karena berdasarkan agama Islam ${ }^{41}$.

Disamping adanya persentuhan dengan kebudayaan lain diluar Budaya Banjar, berkembangnya keyakinan terhadap nilai - nilai hakekat hidup di mana manusia agar bisa tetap eksis harus berusaha memperbaiki hidupnya, menjadi pendorong masyarakat Banjar untuk selalu berusaha meningkatkan kualitas hidupnya dengan berusaha merubah kondisi hidupnya ke arah yang lebih baik dengan membuat sejumlah aturan atau norma yang dipatuhi bersama.

Bertambahnya penduduk yang sangat cepat pada masyarakat Banjar juga berdampak terjadinya perubahan dalam struktur masyarakat terutama dalam lembagalembaga kemasyarakatan (dalam bentuk aturan/norma sosial). Wujud nyatanya adalah seperti munculnya aturan-aturan tertulis (peraturan yang diolah untuk mengatur tata perilaku masyarakat) yang sebelumnya tidak pernah ada. Semakin banyaknya aturan/ norma yang diberlakukan di masyarakat akan membuat individu semakin terikat dengan aturan/norma yang ada.

\section{Analisis Terhadap Hasil Individualisme versus Komunitarisme}

Prosentase hasil Individualisme dalam penelitian ini adalah 20,83 persen dan

\footnotetext{
${ }^{38}$ Ideham dan M. Suriansyah, dkk (editor), Sejarah...h 220

${ }^{39}$ Ibid, h 220

${ }^{40} \mathrm{Ibid}, \mathrm{h} 222$.

${ }^{41}$ Ibid,) h 222
} 
Komunitarisme sebesar 79,17 persen. Hasil penelitian ini sejalan dan memperkuat posisi Indonesia yang tetap dengan budaya individualisme rendah dan komunitarisme tinggi ${ }^{42}$.

Dalam budaya kolektif, seseorang akan belajar untuk berpikir dalam term "Kami" daripada "Saya". Dalam budaya kolektif, pemikiran jalan tengah yang mencerminkan pendapat bersama lebih dihargai. Orang tidak terbiasa untuk memiliki pendapat yang berbeda dengan pendapat kelompok secara umum. Kukuh dalam mempertahankan pendapat pribadi tidak lazim dilakukan dan cenderung dianggap tidak berbudaya.

Di tempat tempat kerja, menciptakan hubungan yang baik antar pribadi atasan dengan bawahan dan juga rekan sejawat adalah hal yang penting sebelum terlibat dalam suatu pekerjaan. Tugas seorang bukan hanya pada fokus pada pekerjaan semata namun juga memperhatikan persoalan-persoalan non teknis di luar pekerjaan seperti: menjaga harmoni kelompok, tidak terlalu menonjolkan diri dan berusaha mengintegrasikan diri pada bagian yang lebih besar yaitu kelompok.

Pembahasan tentang Individualistik dan Komunitarisme di Indonesia tidak dapat dilepaskan dari konsep gotong royong yang masih cukup berakar di Indonesia. Dalam konsep ini, manusia dipersepsikan sebagai mahluk yang tidak dapat berdiri sendiri. Manusia membutuhkan bantuan dari sesamanya terutama dari kaum kerabatnya. Suatu tema berpikir seperti itu akan membawa pada rasa aman bagi nurani yang amat dalam dan mantap kepada masyarakat, karena akan selalu ada bayangan postif dalam hidup, bahagia yang dirasa atau sedang tertimpa bencana. Selalu ada orang lain di sisi manusia yang bersikap kolektif karena permasalahan satu orang adalah juga kepedulian bagi anggota lainnya.

Tolong menolong merupakan kecenderungan alamiah manusia. Setiap individu mempunyai kebutuhan dasar untuk meminta dan memberikan pertolongan pada orang lain. Sebagai mahluk yang lemah tentu seorang manusia akan membutuhkan orang lain untuk meringankan sebagian beban yang dialaminya. Tapi, sebagai mahluk yang dianugrahi kelebihan dan sebagai khalifah di muka bumi, manusia pun mempunyai kuasa dan kewajiban sosial untuk membantu meringankan beban hidup yang dialami orang lain ${ }^{43}$.

Perilaku tolong menolong, secara sosial dan spritual sangat disuakai dan dianjurkan. Secara universal, masyarakat di belahan dunia manapun sangat menyukai orang-orang yang dermawan, suka menolong, kooperatif, solider, dan mau berkorban untuk orang lain. Sebaliknya, orang-orang yang kikir, egois, atau individualistik, sangat tidak disukai masyarakat ${ }^{44}$

Apabila kita kaitkan dengan konteks budaya Banjar, maka temuan penelitian yang menunjukkan rendahnya individualisme dan tingginya komunutarisme tersebut sudah sejalan dengan tata kelakuan di lingkungan dan masyarakat Banjar.

\footnotetext{
${ }^{42}$ Troompenaar, F dan Hampden Turner, F. Riding The Waves of Culture, (London: Nicholas Brealy Publishing, 1997) h. 57

${ }^{43}$ Agus Abdul Rahman, Psikologi Sosial Integrasi Pengetahuan Wabyu dan Pengetabuan Empirik, (Jakarta: RajaGrafindo Persada, 2013) h 218.

${ }^{44}$ Ibid,h 218
} 
Dalam budaya Banjar, kegiatan komunitarisme tergambar pada kegiatan-kegiatan sosial kemasyarakatan dalam hal kerja bergotong royong. Apabila seorang warga mendapat musibah seperti kebakaran, kematian, kecurian, kecelakaan dan sebagainya, maka warga berusaha untuk datang ke tempat warga yang kena musibah tersebut dan bergotong royong untuk membantu menanggulangi musibah ${ }^{45}$. Gotong royong juga dilaksanakan pada saat memperbaiki jalan, membuat saluran air, mendirikan langgar, masjid, pelaksanaan perkawinan, dan lain-lain. Sebelum pekerjaan dimulai dilakukan musyawarah warga masyarakat. Karena yang terlibat adalah masyarakat, maka secara otomatis kegiatan ini mengundang massa untuk bekerja sama ${ }^{46}$.

Semua warga masyarakat yang terlibat dalam kegiatan sosial bersama-sama memiliki hak dan kewajiban yang sama, sehingga harus saling membantu. Anggota masyarakat yang bersedia membantu kegiatan gotong royong maka akan dihargai oleh masyarakatnya. Sebaliknya yang tidak bisa bekerjasama dalam masyarakat akan dicela ${ }^{47}$.

\section{Analisis Terhadap Hasil Netral versus Emosional}

Budaya netral adalah suatu budaya dimana emosi selalu dalam pengontrolan. Orang-orang dalam budaya ini mencoba untuk tidak memperlihatkan perasaan mereka; mereka bertindak dengan mengendalikan emosi dan mempertahankan sebuah ketenangan. Sedangkan budaya emosional adalah budaya dimana emosi-emosi diekpresikan secara terbuka dan spontan/alami. Orang-orang dalam budaya emosional ini cenderung selalu tertawa lebar, berbicara dengan keras ketika merasa keheranan, dan memberi salam dengan antusias ${ }^{48}$.

Menurut William James" ${ }^{49}$, emosi adalah "kecenderungan untuk memiliki perasaan yang khas bila berhadapan dengan objek tertentu dalam lingkungannya. Sedangkan Crow \& Crow (1962) ${ }^{50}$ mengartikan emosi sebagai "suatau keadaan yang bergejolak pada diri individu yang berfungsi sebagai inner adjustment (penyesuaian dari dalam) terhadap lingkungan untuk mencapai kesejahteraan dan keselamatan individu".

Setiap orang memiliki jenis perasaan yang sangat serupa, namun intensitasnya berbeda-beda. Emosi-emosi ini dapat merupakan kecnderungan yang membuat kita menjadi frustasi, tetapi juga menjadi modal untuk meraih kebahagiaan dan keberhasilan hidup. Semua itu bergantung kepada emosi mana yang dipilih dalam bereaksi terhadap orang lain, kejadian-kejadian, dan situasi.

Merujuk pada hasil penelitian Troompenaar ${ }^{51}$, memposisikan Indonesia dalam kategori netral. Sedangkan dalam penelitian ini ditemukan bahwa masyarakat Banjar berada dalam kategori emosional dengan prosentase 73,44 persen. Menurut

\footnotetext{
${ }^{45}$ Ibid, h 217

${ }^{46}$ Ibid, h 225

${ }^{47}$ Ibid, h 225

${ }^{48}$ Tri Dayakisni dan Salis Yuniardi, Psikologi Lintas Budaya, (Malang: UMM Press, 2012). h 61

${ }^{49}$ Alex Sobur, Psikologi Umum dalam Linatasan Sejarah, (Bandung: Pustaka Setia, 2003) h 399-400

${ }^{50}$ Ibid,h 399-400

${ }^{51}$ Troompenaar, F dan Hampden Turner, F. Riding The Waves of Culture, (London: Nicholas Brealy Publishing, 1997) h 70
} 
Ideham, M. Suriansyah, $\mathrm{dkk}^{52}$, dalam masyarakat Banjar sikap hormat, ramah dan sopan dilakukan seseorang kepada orang lain akan selalu berlaku pada situasi yang bagaimanapun.

Gambaran emosional masyarakat Banjar dapat terlihat ketika seorang pemimpin agama dengan pemimpin agama lainnya harus saling menghargai dan hormat menghormati. Dalam hal perbedaan pendapat di antara dua pemimpin, maka pemimpin dapat menyampaikan alasan dan argumennya satu sama dengan tetap berusaha mendapatkan jalan sehingga terdapat kesepakatan di antara mereka. Antara pemimpin dengan pemimpin lainnya tidak boleh ada persaingan atau saling merendahkan ${ }^{53}$.

Orang-orang yang merupakan pengikut dalam memberikan penghormatan dan penghargaan kepada pemimpin agama tidak terbatas hanya pada lembagalembaga keagamaan, tetapi juga di luar lembaga. Jika bertemu di jalan setiap pengikut mengucapkan salam kepada pemimpin agama. Ketika memasuki suatu lembaga pengajian baik yang bertempat di masjid dan surau maupun rumah seseorang, maka harus mengucapkan salam assalamualikum, dan sebelum duduk bersalaman menjabat tangan orang-orang yang telah hadir terlebih dahulu. Apabila masuk bersama-sama orang lain, maka yang mengucapkan salam cukup satu orang yang berada di depan. Kalau sebagian yang hadir dalam ruangan sukar didatangi atau terlalu banyak, biasanya cukup mengucapkan salam sambil sedikit mengangkat tangan kanan ${ }^{54}$. Ketika melaksanakan sebuah upacara atau kegiatan pun pada saat bertemu antar peserta dengan peserta lain di dalam ruangan upacara, sebelum masuk akan memberi salam terlebih dahulu, lalu bersalaman berkeliling. Peserta lain mempersilahkan duduk pada ruangan yang masih kosong berdampingan dengan peserta lainnya ${ }^{55}$.

Dalam pergaulan masyarakat, seseorang berusaha menarik hati orang yang datang ke desanya. Pada umumnya anggota warga suatu tempat bermuka cerah dan riang ketika kedatangan warga masyarakat lainnya ${ }^{56}$.

Kebanyakan ketika pencuri yang tertangkap oleh penduduk cenderung untuk dianiaya oleh para penangkapnya dan kemudian diserahkan kepada pihak polisi untuk diselesaikan. Demikian pula pada saat kecelakaan lalu lintas, yang mengakibatkan korban luka atau meninggal, si sopir selalu dianggap bersalah, dan ada daerah dimana sopir cenderung dianiaya dan kendaraanya cenderung dirusak penduduk, apabila tidak cepat-cepat menghindar dari tempat kejadian. Biasanya si sopir segera melaporkan diri kepada seorang kepala kampung yang berwibawa atau ke kantor polisi terdekat, guna memperoleh perlindungan ${ }^{57}$.

\footnotetext{
${ }^{52}$ Ideham dan M. Suriansyah, dkk (editor), Sejarah Banjar. (Banjarmasin: Pemerintah Provinsi Kalimantan Selatan, 2007) h 217

${ }^{53}$ Ibid, h 220

${ }^{54}$ Ibid, h 221

${ }^{55}$ Ibid, h 224

${ }^{56} \mathrm{Ibid}$, h 226

${ }^{57}$ Alfani Daud, 1997. Islam dan Masyarakat Banjar: Deskeripsi dan Analisis Kebudayaan Banjar, Jakarta: RajaGrafindo Persada, 1997) h 103
} 
Meskipun terkesan emosi masyarakat Banjar cenderung terkendali dan normatif, namun beberapa catatan kasus agresivitas masyarakat Banjar menunjukkan terjadinya kasus agresivitas yang kental dengan muatan SARA. Menurut Djohan Effendi dalam bukunya 'Merayakan Kebebasan Beragama' (2009) menulis bahwa agresivitas muncul sebagai sikap masyarakat Indonesia terhadap anggapan adanya ketidakadilan yang dilakukan oleh penguasa (lembaga-lembaga eksekutif, legislatif, dan yudikatif) sehingga sebagian besar agresivitas ini mengarah kepada hal-hal destruktif atau menghancurkan dan merugikan semua masyarakat kita sendiri ${ }^{58}$.

Masyarakat menjadi agresif apabila terjadi krisis kreativitas di dalam jiwanya sehingga mudah meledak dengan cara-cara yang tidak cerdas. Masyarakat menjadi agresif bila nilai-nilai kearifan dan ajaran sudah tidak lagi menjadi pedoman hidup. Selama ini ajaran agama yang diajarkan di sekolah hanya sebatas pengetahuan, dan itu pun hanya untuk menjawab soal ujian ${ }^{59}$.

Menurut Passe \& Smith $^{60}$, salah satu penyebab munculnya agresi adalah frustasi. Berbagai macam tekanan dan stres dalam hidup, terlebih lagi yang muncul dalam era modern ini, diduga turut memicu bentuk agresi dan kekerasan dalam masyarakat. Masyarakat kini semakin banyak dibebani oleh berbagai macam hal dan permasalahan.

Terlebih lagi di era demokrasi di mana semua hal menjadi layak diperbincangkan, secara tidak langsung itu menambah frustasi di masyarakat. Hal-hal yang dapat menyebabkan frustasi itu adalah saat mengejar sebuah tujuan, bawaan genetis, konflik sosial, kebutuhan untuk mengatur oreang lain, keinginan untuk menguasai secara seksual, nasionalisme, hasrat egois untuk mendapatkan keuantungan pribadi, kesulitan ekonomi, emosi negatif, proyek idealis yang ditujukan untuk membuat dunia menjadi lebih baik dan lain-lain. Selain itu masyarakat juga menjadi agresif karena meniru aksi agresif dari tontonan ${ }^{61}$.

Selain hal tersebut diatas, masyarakat yang terdiri dari kelompok-kelompok sosial yang mempunyai perbedaan latar belakang kebudayaan, ras, ideologi dan sebagainya, mempermudah terjadinya konflik-konflik dalam masyarakat, sehingga sering muncul goncangan- goncangan yang mendorong terjadinya perubahan emosi kehidupan masyarakat.

\section{Analisis Terhadap Hasil Spesifik versus Difusi}

Budaya spesifik adalah budaya dimana individu mempunyai ruang publik yang sangat mereka jaga dan hanya dibagi dengan teman dekat kolega. Dalam budaya spesifik, masyarakat cenderung lebih terbuka, dan ada batas yang jelas antara pekerjaan dan kehidupan pribadi. Sedangkan budaya difusi adalah budaya dimana ruang publik dan ruang pribadi berukuran sama dan individu menjaga ruang publiknya dengan hati-hati, karena memasuki ruang publik sama bernilainya dengan memasuki ruang pribadi. Orang dalam budaya difusi, cenderung lebih berbasa-basi dan tertutup, dan

\footnotetext{
${ }^{58}$ Imam Ratrioso, Rakyat Nggak Jelas Potret Manusia Indonesia Pasca-Reformasi, (Jakarta: Renebook, 2015) h 87

${ }^{59}$ Ibid, h 90

${ }^{60}$ Ibid, h 90

${ }^{61}$ Ibid, h $90-91$
} 
pekerjaan dan kehidupan pribadinya berkait erat ${ }^{62}$.

Dalam budaya Diffuse seperti Indonesia ${ }^{63}$ dan Masyarakat Banjar ${ }^{64}$, maka adalah hal yang lazim ditemukan diluar waktu dinas, ketentuan bahwa yang lebih muda berlaku hormat kepada yang lebih tua masih tetap berlaku. Cara-cara penghormatan dan sikap ramah serta keterbukaan kepada mereka yang bertamu kerumah seorang pemimpin masyarakat juga tetap diegang teguh. Dalam masyarakat suku Banjar sikap hormat, ramah, dan kepatuhan yang dilakukan seseorang kepada orang lain akan selalu berlaku pada sitausi yang bagaimanapun. Apabila ada di antara sesama karyawan yang sakit, karyawan yang lainnya mengunjunginya. Demikian pula pada hari-hari besar seperti Idul Fitri dan Idul Adha, kebiasaan saling mengunjungi berlaku di wilayah birokrasi ${ }^{65}$.

Sangat menarik apabila melihat dari hasil penelitian ini, karena ternyata ada pergeseran dimensi budaya yang terjadi di masyarakat Banjar. Berdasarakan hasil pengkategorian menunjukkan perubahan dimensi dari yang awalnya Diffuse menuju kepada Spesifik. Dimensi budaya Diffuse adalah 45,83 persen sedangkan Dimensi Budaya Spesifik adalah 54,17 persen. Meskipun tidak secara signifikan namun data prosentase tersebut memberikan sebuah gambaran adanya perubahan dimensi budaya di masyarakat Banjar.

Menurut Ideham, M. Suriansyah, dkk (editor) ${ }^{66}$, gambaran masyarakat Banjar yang spesifik terlihat di dalam hubungan pekerjaan, yaitu seorang karyawan tidak akan mencampuri tugas, pekerjaan atau kebijaksaan yang diambil karyawan lainnya, selama yang bersangkutan tidak meminta pertimbangannya. Kecuali kalau apa yang dilakukan seorang karywan tersebut nyata-nyata merugikan lembaga atau karyawan lainnya, baru seorang karyawan boleh memperingatkannya.

Menurut penelitian yang dilakukan oleh Alfani Daud dengan judul "Pembenihan serta Pemupukan TataNilai Sosial Budaya dalam Keluarga Indonesia Untuk Daerah Kalimantan Selatan", digambarkan tentang makna hidup yang sudah membaku dalam masyarakat Banjar ialah "hidup untuk bekerja" dan "hidup untuk beramal-ibadah" 67. Orang Banjar dalam bekerja haruslah menyeimbangkan antara kepentingan dunia dan akhirat. Hidup ini harus diisi dengan kerja keras, sekaligus juga berdoa dan beribadah kepada Allah SW'T. Hal ini memberikan bahwa bagi orang Banjar dua hal tersebut dapat dilakukan secara bersama-sama.

Agama Islam mengajarkan agar umatnya selalu mengadakan keseimbangan antara persiapan untuk kehidupan di akhirat dan kehidupan di dunia. "carilah pada apa yang telah diberikan Allah untuk akhirat, tetapi jangan lupakan bagian kamu di dunia (Q.S. 28:77). Tekanan selalu diberikan kedua-duanya, atau dengan perkataan lain, nilai "hidup untuk bekerja" dan "nilai untuk beramal-ibadah" harus selalu berkembang

\footnotetext{
${ }^{62}$ Troompenaar, F dan Hampden Turner, F. Riding The Waves of Culture, (London: Nicholas Brealy Publishing, 1997) h 88

${ }^{63} \mathrm{Ibid}$, h 88

${ }^{64}$ Ideham dan M. Suriansyah, dkk (editor), Sejarah Banjar. (Banjarmasin: Pemerintah Provinsi Kalimantan Selatan, 2007) h 217

${ }^{65} \mathrm{Ibid}$, h 217

${ }^{66} \mathrm{Ibid}$, h $218-219$

${ }^{67}$ Sahriansyah, Sejarah Kesultanan dan Budaya Banjar.(Banjarmasin : Antasari Press, 2015) h 32
} 
sama kuat. Di dalam Al Quran umat Islam diperintah untuk meninggalkan urusan duniawi jika panggilan untuk beribadah telah dikumandangkan, tetapi setelah ibadah selesai dikerjakan masing-masing disusuh untuk berusaha sungguh-sungguh mencari nafkah. Namun dalam pada itu tetap ditekankan agar ketika sibuk mencari nafkah itu selalu dalam keadaan ingat kepada Tuhan ${ }^{68}$.

Adanya pergeseran dimensi budaya ini mungkin karena adanya perbedaan antara pola tata nilai orang tua dan pola tata nilai remaja. Sehingga dapat dikatakan bahwa nilai-nilai diffuse tidak berhasil diteruskan oleh para generasi orang tua kepada generasi remaja. Nilai hidup untuk beramal-ibadah dalam kalangan orang tua berada dalam posisi agak kuat dan bergeser menjadi lemah ketika berada di kalangan remaja. Demikian juga sebaliknya, hidup untuk bekerja menguat pada kalangan remaja dan melemah pada kalangan orang tua.

Karena pengaruh kehidupan modern maka para pemuda Banjar gaya hidupnya sudah mengarah ke materialis pragmatis yaitu cenderung kepada kepentingan praktis dalam kehidupan ${ }^{69}$, sehingga pola hidup orang Banjar sangat konsumtif. Hal ini dapat dilihat dengan menjamurnya warung makan di pinggir jalan sampai restoran yang selalu dipandati pengunjung untuk menikmati berbagai jenis makanan yang disajikan. Realitas ini bertolak belakang kondisi yang terjadi di mesjid atau langgar yang cenderung sepi dari remaja dan hanya diisi oleh orang yang sudah tua untuk menikmati hidup dan beribadah kepada Allah untuk mengisi waktu ${ }^{70}$.

\section{Analisis Terhadap Hasil Achivement versus Ascription}

Budaya prestasi (acbivement culture) adalah budaya dimana orang-orang memberi status berdasar pada sejauhmana kualitas (baiknya) mereka menampilkan fungsi mereka. Sedangkan ascription culture adalah budaya dimana status diatribusikan berdasarkan pada siapa atau apakah orang itu. Budaya prestasi memberikan status tinggi kepada mereka yang prestasinya tinggi. Sementara ascription culture memberikan status berdasarkan pada usia, gender, atau koneksi sosial ${ }^{71}$.

Selain itu, budaya yang bersifat achievement adalah budaya yang menilai tinggi mutu dan ketelitian sebagai hasil karya unggul dari manusia. Sasaran orientasi karya nya harus merupakan karya itu sendiri, bukan berupa harta untuk dikonsumsi atau kedudukan sosial yang menambah gengsi ${ }^{72}$.

Dalam masyarakat dengan ascription tinggi seperti Indonesia ${ }^{73}$, simbol-simbol status diterima sebagai sesuatu hal yang wajar. Gelar-gelar keagamaan, akademis dan penghormatan lain dilihat sebagai sesuatu yang penting. Status seseorang banyak ditentukan oleh gelar-gelar formal yang menunjukkan siapa orang tersebut (ascribed status) dan bukan apa yang telah di capai oleh orang tersebut (acbieved status).

\footnotetext{
${ }^{68}$ Ibid, h 35

${ }^{69}$ Ibid, h 37

${ }^{70}$ Ibid, h 36-37

${ }^{71}$ Tri Dayakisni dan Salis Yuniardi, Psikologi Lintas Budaya, (Malang: UMM Press, 2012). h 61-62

${ }^{72}$ Koenjraningrat, Pengantar Ilmu Antrapologi, (Jakarta: Rineka Cipta, 2002) h 35

${ }^{73}$ Troompenaar, F dan Hampden Turner, F. Riding The Waves of Culture, (London: Nicholas Brealy Publishing, 1997) h 105
} 
Pola hubungan kerja antara atasan dan bawahan di tempat kerja merupakan buah dari pendidikan di rumah dan disekolah. Di rumah, orang tua adalah sumber kebaikan dan moralitas yang ditunjukkan dengan mencium tangan sebelum pergi dan pulang sekolah atau segala kegiatan di luar rumah yang memerlukan waktu dan jarak cukup jauh. Hormat kepada orang yang lebih tua diajarkan dalam kehidupan sehari-hari, sehingga mendengarkan nasehat atau petuah merupakan tradisi penting sebelum melakukan kegiatan yang dianggap penting.

Oleh karena itu, bukan hal yang aneh apabila seorang yang dianggap pemimpin akan dipanggil Bapak atau Ibu, meskipun umurnya jauh lebih muda, yang merefleksikan hubungan antara anak dan orang tuanya. Pola hubungan ini tidak akan ditemukan pada negara-negara Barat yang memiliki Achievement culture yang tinggi, dimana menyebut nama langsung dalam hubungan atasan-bawahan, lebih menjadi keseharian.

Dalam budaya Banjar pun, hal demikian masih sering ditemukan, antara atasan yang lebih tinggi tetap berpatokan pada usia masing-masing. Begitu pula atasan dengan bawahan, faktor umur merupakan hal yang patut diperhatikan. Sehingga jika bawahan yang lebih tua usianya menggunakan aku dan ikam kepada atasannya yang lebih muda umurnya, maka hal tersebut bukanlah melanggar aturan. Sebaliknya seorang atasan yang usianya lebih muda selalu menggunakan sebutan ulun pian kepada bawahannya yang lebih tua umurnya. Akan tetapi dalam masyarakat Banjar biasanya menghargai jabatan seseorang. Karenanya bahawan yang usianya lebih tua daripada atasannya juga menggunakan ulun-pian dalam percakapan, sedang atasannya juga menggunakan sebutan demikian ${ }^{74}$.

Dalam tata kelakuan dalam ranah pendidikan yang meliputi lembaga pendidikan dari yang paling rendah sampai tertinggi, serta keterlibatan orang tua maka dalam masyarakat Banjar seorang Kepala Pendidikan harus membimbing dan menjadi teladan bagi guru atau dosen yang membantunya. Mereka harus saling menghormati hak dan wewenang masing-masing. Guru yang lebih muda harus menghormati guru yang lebih tua, harus bekerjasama dan memberikan bantuan satu sama lainnya ${ }^{75}$.

Tingkahlaku seorang guru atau dosen haruslah menjadi panutan bagi muridmuridnya. Sebagai pendidik, harus memberiu teladan yang baik dan terpuji. Sikap dan perbuatan bahkan sampai pada cara berpakaian perlu diperhatikan oleh seorang pendidik. Apabila seorang pendidik melakukan hal-hal yang tidak baik, menyebabkan hilangnya wibawa di hadapan murid-muridnya ${ }^{76}$.

Murid harus menghormati gurunya. Kalau bertemu di jalan ia harus menyapa lebih dahulu. Jika murid berjalan beriringan dengan guru, ia akan mempersilahkan guru untuk berjalan di depan. Pada waktu masuk ruang kelas, ternyata di depan pintu berdiri seorang guru, maka yang melewatinya harus membungkukkan badan ${ }^{77}$.

Dalam berbicara murid menggunakan sebutan ulun untuknya dan pian untuk sebutan gurunya serta mengiyakan percakapan gurunya dengan percakapan inggih,

\footnotetext{
${ }^{74}$ Ideham dan M. Suriansyah, dkk (editor), Sejarah Banjar. (Banjarmasin: Pemerintah Provinsi Kalimantan Selatan, 2007) h 217

${ }^{75}$ Ibid, h 219

${ }^{76}$ Ibid, h 219

${ }^{77}$ Ibid, h 219
} 
kalau dipanggil harus menyahut dengan dengan pun. Seorang murid berbicara pada guru seperti halnya seorang anak berbicara kepada orang tuanya. Murid memanggil guru dengan sebutan Bapak atau Ibu, Murid tidak boleh berbicara keras atau mengatasi pembicaraan guru ${ }^{78}$.

Berbeda dengan hasil penelitian Troompenar dan gambaran tata kelakuan masyarakat Banjar yang menempatkan Indonesia dan masyarakat Banjar dalam posisi Ascription Culture. Penelitian ini menunjukkan skor Achievement yang tinggi yaitu 76,04 persen sedangkan Ascription nya hanya 23,96 persen. Tingkat persepsi terhadap dimensi budaya Achievement yang tinggi ini menunjukkan adanya proses pergeseran dimensi budaya yang awalnya ascription menuju prioritas achievement, yaitu penguatan kepada orientasi assertivenes, uang, materi dan kesuksesan. Perubahan kutub nilai budaya ini mungkin disebabkan makin kuatnya budaya materi karena tuntutan hidup yang semakin memerlukan uang dan apresiasi yang tinggi terhadap penampilan fisik seseorang.

Selain itu, masyarakat Banjar yang mewarisi karakter masyarakat feodal zaman Kerajaan Banjar, tampaknya tidak banyak mempengaruhi perkembangan budaya masyarakat Banjar. Karakter masyarakat feodal yang menonjolkan asal usul dan asesori diri serta memandang martabat dari peranan dan kekuasaan, tampaknya tidak terwariskan karena memang tokoh sentralnya (sultan atau raja) tak berlanjut sejak dihapuskannya Kerajaan Banjar oleh Belanda sejak abad ke 19, juga tidak sejalan dengan ajaran Islam yang dianut masyarakat, yang memandang manusia sama di hadapan Allah kecuali dari segi ibadahnya ${ }^{79}$.

Sistem pelapisan masyarakat yang terbuka merupakan sistem yang memberikan peluang atau kesempatan kepada setiap warga masyarakat untuk mengalami mobilitas sosial vertikal secara luas, dimana setiap warga masyarakat memiliki kesempatan untuk meraih prestasi dan memiliki kedudukan/status sosial yang lebih tinggi.

Adanya kontak dengan kebudayaan lain sebagai kebudayaan baru juga berperan dalam terjadinya perubahan nilai budaya, sehingga menghasilkan perubahan secara perlahan-lahan di budaya masyarakat Banjar. Pendidikan juga memberikan kontribusi positif terjadi perubahan sosial di masyarakat Banjar, pendidikan akan memberikan nilai-nilai tertentu kepada manusia, terutama dalam membuka pikirannya, menerima hal - hal baru, maupun cara berfikir secara ilmiah. Pendidikan mengajarkan manusia untuk dapat berfikir secara obyektif, rasional dan melihat ke masa depan, berusaha menciptakan kehidupan yang lebih maju.

\section{Analisis Terhadap Hasil Sikap Terhadap Waktu}

Troompenaar ${ }^{80}$ mengidentifikasikan dua pendekatan yang berbeda dalam persfektif waktu, yaitu sequential dan synchronous. Menurut Dayakisni dan Yuniardi ${ }^{81}$,

\footnotetext{
${ }^{78}$ Ibid, h 219

${ }^{79}$ Nawawi, Ramli. 2014 Perihal Keberadaan Nilai Budaya Orang Banjar (Kalimantan Selatan). dalam http:/ / ramlinawawiutun.blogspot.co.id/2014/03/perihal-keberadaan-nilai-budaya-orang. diakses Jumat, 1 Juli 2016

${ }^{80}$ Troompenaar, F dan Hampden Turner, F. Riding The Waves of Culture, (London: Nicholas Brealy Publishing, 1997) h 123

${ }^{81}$ Tri Dayakisni dan Salis Yuniardi, Psikologi Lintas Budaya, (Malang: UMM Press, 2012). h 62
} 
dalam budaya dengan pendekatan sequential adalah umum orang-orang cenderung untuk hanya melakukan satu aktifitas pada satu waktu, mempertahankan janji dengan ketat, dan menunjukkan pilihan yang kuat untuk mengikuti rencana-rencana sebagaimana yang telah ditetapkan dan tidak menyimpang dari rencana tersebut. Sementara dalam budaya dengan pendekatan syynchronous, orang cenderung untuk melakukan lebih dari satu aktifitas pada satu waktu, janji adalah kira-kira dan kemungkinan dirubah pada saat tertentu dan penjadwalan pada umumnya dibawah kepentingan hubungan dan dibolehkan untuk melakukan interupsi atas jadwal tersebut. Bagi orang-orang yang berasal dari budaya Synchronous adalah hal yang biasa akan menghentikan apa yang mereka lakukan untuk bertemu dan menyambut individuindividu yang datang ke kantor mereka.

Menurut penelitian yang dilakukan oleh Troompenaar ${ }^{82}$ menposisikan Indonesia kedalam kategori Budaya Synchronous, dan demikian pula dalam penelitian yang dilakukan ini menposisikan masyarakat Banjar dalam posisi kategori Budaya Synchronous (69,79 persen).

Di Indonesia, dan termasuk juga dalam masyarakat Banjar. Waktu dipandang sangat relatif. Di masyarakat dikenal istilah "Jam Karet". Istilah ini menunjukkan toleransi pada waktu. Contoh sederhana adalah ketika memiliki janji dengan seseorang pada pukul 10 pagi, maka kita tidak dapat menjamin bahwa pukul 10 kita sudah saling bertemu. Karena pandangan orang terhadap waktu itu bersifat relatif maka siapa tahu bagi teman kita pukul 10 itu sudah harus ditempat, lalu kita menggangap kita sudah berangkat pukul 10. Pada kebanyakan kasus, jam karet lebih banyak berkaitan dengan penguluran waktu beberapa saat di luar waktu yang telah ditetapkan.

Menurut Djamaluddin Ancok ${ }^{83}$, banyak faktor yang diperkirakan mempuanyai kaitan erat dengan tumbuh dan berkembangnya kebiasaan jam karet, faktor-faktor tersebut antara lain: Pertama, yaitu masyarakat Indonesia yang agraris. Masyarakat Indonesia adalah masyarakat agraris yang sangat bergantung pada bidang pertanian dalam menopang kehidupan ekonomi. Mayoritas penduduk Indonesia, termasuk kakek dan neneknya, adalah petani. Pekerjaan sebagai petani ini tidak terlalu menuntut ketepatan waktu di bidang industri. Orang dapat pergi ke sawah kapan saja, pagi, siang, atau sore. Lain halnya dengan para pekerja di dalam industri yang jam kerjanya sangat diatur oleh perusahaan. Pada pekerjaan industri, keterlambatan datang ke tempat kerja akan menyebabkan turunnya produktivitas kerja.

Kedua, sikap pemuka masyarakat. Yang dimaksudkan di sini adalah sikap pemuka masyarakat yang menduduki jabatan formal, seperti kepala desa, camat, kepala kantor, dan lain-lain. Ada kecenderungan bahwa pemuka masyarakat ini di dalam beberapa kegiatan selalu harus ditunggu oleh bawahannya, bukan menunggu bawahannya. Di dalam kegiatan rapat misalnya, biasanya pimpinanlah yang datang paling akhir. Setelah pimpinan datang, rapat baru dimulai. Keterlambatan ini tidak berarti bahwa pimpinan terlambat tiba atau datang di tempat rapat. Cukup sering pimpinan sudah berada di kantor. Pimpinan terlambat datang karena dia biasanya menghendaki semua

\footnotetext{
${ }^{82}$ Troompenaar, F dan Hampden Turner, F. Riding...h 123

${ }^{83}$ Djamaluddin Ancok, Psikologi Terapan, (Yogyakarta: Darussalam, 2004). h 30
} 
orang lain sudah hadir. Satu hal lain yang membuat pimpinan atau juga orang lain suka terlambat dalam mengerjakan sesuatu kegiatan yang telah ditetapkan, adalah kebiasaan memegang jabatan rangkap. Makin banyak jabatan yang dipegang maka akan makin besar kemungkinan untuk membiasakan diri dengan jam karet. Hanya segelintir manusia dengan disiplin sangat tinggi yang dapat mempertahankan ketepatan waktu kerja dalam kondisi jabatan yang demikian.

Ketiga, sistem penilaian prestasi. Ketepatan waktu di dalam melaksanakan suatu pekerjaan adalah salah satu tolak ukur keberhasilan kerja. Namun seringkali dalam kenyataannya mereka 'yang tepat-waktu' dan 'yang terlambat' diperlakukan sama saja. kondisi karyawan tidak dinilai dari ketepatan waktu tersebut. Jarang sekali orang-orang yang tepat-waktu mendapat penghargaan. Demikian pula dengan aspek kehidupan masyarakat di luar kantor atau perusahaan. Seringkali keterlambatan tidak menimbulkan konsekuensi apa-apa. Misalnya kalau terlambat datang ke stasiun kereta api untuk membeli karcis, seseorang tidak perlu antri. Ia dapat secara langsung menyerobot di depan orang lain tanpa konsekuensi apa-apa. Tidak ada yang menegur apakah petugas atau orang lain yang dalam antrian.

Sifat tidak suka memberi kritik itu semakin menonjol bila orang yang melakukan jam karet itu adalah pimpinan. Ada rasa kuatir bahwa kritik terhadap pimpinan itu akan mencelekakan dirinya. Daripada membuat masalah lebih baik diam saja. Upaya pemberantasan jam karet ini sangat ditentukan oleh sikap pimpinan formal.

Keempat, sikap masyarakat yang rikuh dan tidak berterus terang. Sifat atau nonasertif ditandai oleh adanya perasaan segan untuk mengatakan sesuatu perbuatan orang lain yang dianggap kurang wajar. Keseganan ini timbul karena adanya kekhawatiran bahwa teguran yang disampaikan akan membuat orang lain menjadi tersinggung perasaannya. Sifat yang demikian akan membuat orang tidak bersedia untuk mengkritik perilaku jam karet.

Kelima, sikap masyarakat yang menyerah pada keadaan. Jika ditinjau dari cara manusia melihat faktor yang mempengaruhi kehidupannya, secara garis besar manusia dapat digolongkan ke dalam dua tipe. Tipe pertama disebut dengan pusat kendali internal (internal locus of control) yang melihat kemajuan di dalam hidup ditentukan oleh faktor-faktor di dalam diri seperti bekerja keras, cita-cita yang tinggi, dan keuletan dalam mengubah nasib. Orang tipe ini yakin bahwa kemajuan dirinya ditentukan oleh dia sendiri. Tipe yang kedua adalah pusat kendali eksternal (external locus of control). Orang yang termasuk ke dalam tipe ini beranggapan bahwa faktorfaktor di luar dirilah yang menentukan keberhasilan seseorang. Misalnya karena nasib naik, adanya koneksi, dan bukan karena kerja keras dari diri sendiri. Orang tipe ini beranggapan bahwa bekerja keras, menepati waktu, bekerja penuh disiplin bukanlah faktor utama penyebab keberhasilan untuk menduduki posisi tertentu. Faktor yang paling menentukan adalah ada tidaknya koneksi, khususnya koneksi yang masih ada kaitan keluarga. Dalam masyarakat yang menganut prinsip kekeluargaan sifat subjektif untuk mengutamakan anggota kelaurga sendiri sangatlah besar. Kalau sekiranya anggota keluarga diberi kesempatan tersebut memang memiliki kemampuan untuk melaksanakan tugas yang diberikan sistem koneksi tidak memberikan pengaruh yang fatal. Tetapi kalau anggota keluarga yang diberikan kesempatan tersebut tidak memiliki 
kualifikasi yang dituntut oleh pekerjaan maka akibatnya akan fatal. Dalam masyarakat kita sering terdengar selorohan seperti 'sedulurisasi' dalam hal untuk mendapatkan kesempatan. Suasana masyarakat yang demikian ini akan membuat orang kurang yakin bahwa disiplin di dalam menggunakan waktu akan mengantarkan seseorang ke kemajuan karir diri sendiri.

Selain menganggap waktu itu relatif yang mengarah pada perilaku jam karet, masyarakat Indonesia tidak terkecuali masyarakat Banjar juga masih banyak yang menggagap bahwa ada hari tertentu yang memiliki peruntungan yang baik dan hari naas serta hari yang baik untuk melakukan sesuatu ${ }^{84}$. Hal ini tidak lepas dari kepercayaan orang tua dahulu yang belum bisa lepas seutuhnya dari tradisi turun temurun meski gaya hidup sudah dipengaruhi oleh budaya Barat.

Masyarakat Banjar tidak mempunyai nama-nama bulan dan nama hari sendiri. Nama-nama bulan yang biasa dipakai ialah nama-nama bulan Arab (dengan perubahan bunyi) atau dinamakan sesuai dengan peristiwa atau kegiatan upacara yang biasa dilakukan waktu itu ${ }^{85}$.

Waktu sehari dan semalam dibagi atas kelompok-kelompok waktu yang disesuaikan dengan waktu sembahyang. Maka terdapatlah waktu subuh, saat orang sembahyang subuh, waktu duba, saat orang bersembahyang sunat duha, waktu zubur atau juhur (saat bersembahyang zuhur), waktu asar (saat bersembahyang asr), waktu magrib (saat bersembahyang magrib), waktu isya (saat bersembahyang isya). Selain itu digunakan pula istilah limbah isya untuk waktu sesudah orang selesai bersembahyang isya (dimulai kira-kira jam 8.30 malam) tangah malam (tengah malam), dan dinihariatau kadang-kadang waktu (makan) sahur (dimulai kira-kira jam 02.00) untuk melengkapi waktu-waktu tersebut ${ }^{86}$.

Pembagian waktu yang lain lagi disesuaikan dengan jalannya matahari, yaitu pagi-pagi, tangah naike ([matahari] tengah naik, tangah hari( tengah hari), tangah turun ([matahari] tengah turun), dan petang hari (petang hari); yang terkahir ini sering dinamakan pubun kamarian. Pembagian waktu pagi-pagi, tangah naik dan seterusnya ini biasanya digunakan untuk meramal atau untuk menentukan saat yang tepat untuk turun piturun meskipun sudah ada yang menyebut jamnya ${ }^{87}$.

\section{Analisis Terhadap Hasil Sikap Terhadap Lingkungan}

Sejalan dengan penelitian Troompenar ${ }^{88}$ yang menempatkan Indonesia pada posisi Outer directed, penelitian ini juga menunjukkan outer directed pada budaya Banjar berada pada posisi dominan yaitu sebesar 83,33 persen sedangkan inner directed nya hanya sebesar 16,67 persen.

\footnotetext{
${ }^{84}$ Alfani Daud, 1997. Islam dan Masyarakat Banjar: Deskripsi dan Analisis Kebudayaan Banjar, Jakarta: RajaGrafindo Persada, 1997) h. 366

${ }^{85}$ Ibid, h 367

${ }^{86} \mathrm{Ibid}$, h 368

${ }^{87}$ Ibid, h 368

${ }^{88}$ Troompenaar, F dan Hampden Turner, F. Riding The Waves of Culture, (London: Nicholas Brealy Publishing, 1997) h 143
} 
Perhatian khusus sikap pada lingkungan ini diarahkan pada bagaimana mereka memiliki keyakinan dalam mengendalikan atau mengontrol hasil (inner directed) atau membiarkan sesuatu di luar diri mengendalikan dirinya (Outer directed). Misalnya seseorang yang memiliki keyakinan dalam mengendalikan lingkungannya akan memilih pilihan pertama yaitu inner directed; dan percaya bahwa apa yang terjadi pada mereka adalah perbuatan mereka sendiri. Di Amerika, seseorang merasa sangat yakin bahwa mereka menguasai nasib mereka sendiri. Hal inilah yang menyebabkan sikap dominan mengarah pada lingkungan dan tidak senang ketika mendapatkan sesuatu di luar kendali mereka. Sebaliknya, beberapa negara Asia termasuk Indonesia di dalamnya memiliki keyakinan bahwa segala sesuatu bergerak atau berubah secara alami dan seseorang seharusnya "menempuhnya dengan mengalir", sehingga sikap fleksibel, yang ditandai oleh ciri adanya kesediaan untuk kompromi dan mempertahankan harmoni dengan alam adalah menjadi penting

Manusia dengan pengetahuannya dapat mempengaruhi, mengubah, dan membentuk lingkungan yang dapat memberikan sumber kehidupan sesuai dengan apa yang dibutuhkan. Hubungan manusia dengan lingkungan dijembatani oleh pola kebudayaan. Melalui kebudayaan inilah manusia belajar mengadaftasikan dirinya dengan keadaan lingkungannya supaya tetap bertahan dalam kehidupannya. dalam beradaftasi dan mendayagunakan alam lingkungannya itu mereka berusaha melakukannya dengan cermat, penuh kehati-hatian dan terarah agar bisa menunjang kebutuhan hidup ${ }^{89}$

Berbagai peristiwa alam senantiasa dialami dalam perputaran waktu, yang kadang karena berulang-ulang terjadinya akhirnya dapat diperhitungkan gejala-gejalanya. Nmanusia yang berdasarkan pengalamannya menghadapi perubahan alam, terutama yang berkaitan dengan sumber kehidupan mereka berusaha untuk memahami keadaan lingkungannya. Pengalaman yang dialami itu pada gilirannya menjadi sumber acuan dalam melakukan pekerjaan. Demikian juga yang terjadi dengan masyarakat Banjar yang mayoritas petani, memiliki pengetahuan khusus tentang cara memulai pekerjaan dan beradaftasi dengan lingkunganny $a^{90}$.

Kepedulian masyarakat Banjar terhadap lingkungannya sesuai dengan ajaran agama Islam yang mayoritas dianut. Masyarakat Banjar menganggap lingkungan merupakan faktor produksi dan bahan konsumsi yang diberikan oleh Tuhan kepada manusia untuk dinikmati dan dipelihara. Jadi dengan dasar itu, perlakuan masyarakat Banjar terhadap lingkungannya sangat tergantung pada pandangan mereka sendiri, mau berbuat kearifan atau tidak terhadap lingkungannya. Dalam konsep dasar pandangan urang Banjar sesungguhnya telah tertanam suatu prinsip bahwa Tuhan telah menciptakan dan mengatur kebutuhan hidup manusia. Alam semesta diciptakan Tuhan untuk kesejahteraan umat manusia. Tuhan menentukan tata tertib hidup yang khusus bagi manusia, namun Tuhan juga memberikan keleluasaan untuk mengatur hidup dan kehidupan dalam lingkungannya ${ }^{91}$.

\footnotetext{
${ }^{89}$ Ideham dan M. Suriansyah, dkk (editor), Sejarah...h 239

${ }^{90}$ Ibid, h 239

${ }^{91}$ Ibid, h. 239
} 
Dalam upaya pemeliharaan lingkungan, masyarakat Banjar selalu berpedoman pada prinsip agama Islam. Sumber utamanya adalah Al Quran dan Sunnah yang banyak sekali berisi ayat-ayat yang menyiratkan pengelolaan dan pemeliharaan lingkungan serta bagaimana harus beradaftasi dengan lingkungan hidup ${ }^{92}$.

\section{Simpulan}

Adanya perbedaan nilai Budaya Indoensia dengan nilai budaya Urang Banjar menunjukkan bahwa perubahan kehidupan masyarakat khususnya masyarakat Banjar berlangsung terus-menerus dan tidak akan pernah berhenti, karena tidak ada satu masyarakatpun yang berhenti pada suatu titik tertentu sepanjang masa.

Berlangsungnya perubahan dimensi nilai budaya pada masyarakat Banjar ini merupakan bukti nyata dari berlangsungnya perubahan sosial di dalam masyarakat Banjar. Setidaknya terdapat sejumlah faktor-faktor yang mempengaruhi yang dapat menjadi faktor pendorong dan faktor penghambat terjadinya proses perubahan sosial di masyarakat Banjar yaitu: kontak dengan kebudayaan lain, adanya sistem pendidikan formal yang maju, sistem stratifikasi sosial masyarakat Banjar yang terbuka, masyarakat Banjar yang semakin heterogen, adanya ketidakpuasan masyarakat Banjar terhadap berbagai bidang kehidupan, pandangan bahwa manusia harus senantiasa memperbaiki hidupnya,

\section{Daftar Pustaka}

Abdul Rahman, Agus. 2013. Psikologi Sosial Integrasi Pengetahuan Wahyu dan Pengetahuan Empirik. Jakarta: RajaGrafindo Persada.

Ancok, Djamaluddin. 2004. Psikologi Terapan. Yogyakarta: Darussalam.

Aseeri, Akh. Fauzi, dkk. 2009. Alfani Daud: Riwayat dan Pemikirannya. Banjarmasin: Antasari Press.

Daud, Alfani. 1997. Islam dan Masyarakat Banjar: Deskripsi dan Analisis Kebudayaan Banjar. Jakarta: RajaGrafindo Persada.

Dayakisni, Tri. Yuniardi, Salis. 2012. Psikologi Lintas Budaya. Malang: UMM Press.

Ideham, M. Suriansyah, dkk (editor). 2007. Sejarah Banjar. Banjarmasin: Pemerintah Provinsi Kalimantan Selatan.

Kluckhon, F.R dan Stradtbeck, F.L. 1961. Variations in value orientation. Evanston: Row Peterson.

Koentjaraningrat. 1987. Pengantar Ilmu Antropologi. Jakarta: Balai Pustaka.

Koentjorongrat. 1984. Kebudayaan Jawa. Jakarta: Balai Pustaka.

Koenjaraningrat. 1996. Pengantar Ilmu Antropologi. Jakarta: Rineka Cipta.

Koenjaraningrat. 2002. Pengantar Ilmu Antropologi. Jakarta: Rineka Cipta

Mardiatmaja. 1986. Tantangan Dunia Pendidikan. Jogyakarta: Kanisius.

Melalatoa, Junus M. ed. 1997. Sistem Budaya Indonesia, Jakarta: Kerjasama FISIP Universitas Indonesia dengan PT. Pamator

${ }^{92}$ Ibid, h 240 
Moeis, Syarif. 2009. Pembentukan Kebudayaan Nasional Indonesia, Makalah. Bandung: Universitas Pendidikan Indonesia.

Nawawi, Ramli. 2014 Perihal Keberadaan Nilai Budaya Orang Banjar (Kalimantan Selatan). dalam http://ramlinawawiutun.blogspot.co.id/2014/03/perihalkeberadaan-nilai-budaya-orang. diakses Jumat, 1 Juli 2016.

Noor, Irfan. 2003. Ulama dan Masyarakat Banjar. Dalam Jurnal Kandil Melintas Tradisi Edisi 1, Tabun I. Mei 2003 hal 18-25.

Noor, Yusliani, 2016. Islamisasi Banjarmasin Abad ke-15 Sampai Ke-19. Yogyakarta: Penerbit Ombak.

Ratrioso, Imam. 2015. Rakyat Nggak Jelas Potret Manusia Indonesia Pasca-Reformasi. Jakarta: Renebook.

Sahriansyah. 2015. Sejarah Kesultanan dan Budaya Banjar. Banjarmasin : Antasari Press.

Saleh, M. Idwar. 1986. Sekilas Mengenal Daerah Banjar dan Kebudayaan Sungainya Sampai Dengan Akbir Abad 19. Banjarbaru: Museum Negeri Lambung Mangkurat Provinsi Kalimantan Selatan.

Sobur, Alex. 2003. Psikologi Umum dalam Linatasan Sejarah. Bandung: Pustaka Setia.

Sulaiman, Munandar. 1992. Ilmu Budaya Dasar Suatu Pengantar. Bandung: Refika Aditama.

T. Morden. 1999. Models Of National Culture-A Management Review. Cross Cultural Management(An International Journal 6 (1). Hal 19-44.

Tim Indohun. Tahun Tidak ada. Pedoman Aplikeasi Soft Skill One Health. Jakarta: Fakultas Kesehatan Masyarakat Universitas Indonesia.

Troompenaar, F dan Hampden Turner, F. 1997. Riding The Waves of Culture. London: Nicholas Brealy Publishing.

Usman A. Gazali. 1995/1996. Urang Banjar Dalam Sejarah. Banjarmasin: Lambung Mangkurat University Press. 